\title{
The main anammox-based processes, the involved microbes and the novel process concept from the application perspective
}

\author{
Yan Guo ${ }^{1,2}$, Zibin Luo ${ }^{2}$, Junhao Shen ${ }^{3}$, Yu-You Li $(\bowtie)^{2,3}$ \\ 1 Department of Environmental Engineering, School of Energy and Environmental Engineering, University of Science and Technology Beijing, \\ Beijing 100083, China \\ 2 Department of Civil and Environmental Engineering, Graduate School of Engineering, Tohoku University, Sendai, Miyagi 980-8579, Japan \\ 3 Graduate School of Environmental Studies, Tohoku University, Sendai, Miyagi 980-8579, Japan
}

\section{H I G H L I G H T S}

- The PNA, denitratation/anammox, and DAMO/ anammox process are reviewed together.

- Denitratation/anammox-based process is promising in mainstream treatment.

- DAMO and denitratation processes realize the higher nitrogen removal efficiency.

- The utilization of metabolism diversity of functional microbe is worth exploring.

- An effective waste treatment system concept is proposed.

\section{A R T I C L I N F O}

Article history:

Received 29 June 2021

Revised 31 August 2021

Accepted 25 September 2021

Available online 1 November 2021

Keywords:

Anammox

Nitritation

Denitratation

Denitrifying anaerobic methane oxidation

Mainstream wastewater

\section{G R A P H C A B S T R A C T}

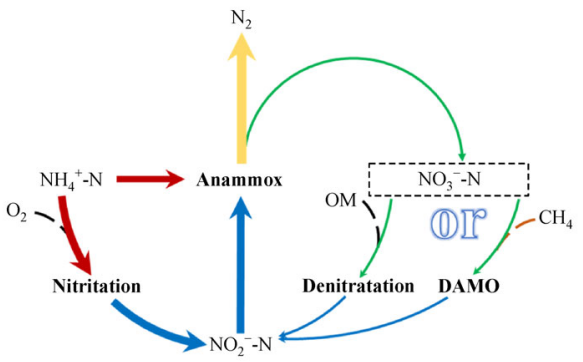

A B S T R A C T

Anammox technology has been widely researched over the past 40 -year from the laboratory-scale to full-scale. It is well-known that in actual applications, the solo application of anammox is not feasible. Since both ammonium and nitrite are prerequisites based on the reaction mechanism, the pre-treatment of wastewater is necessary. With the combination of anammox process and other pre-treatment processes to treat the actual wastewater, many types of anammox-based processes have been developed with distinct nitrogen removal performance. Thus, in order to heighten the awareness of researchers to the developments and accelerate the application of these processes to the treatment of actual wastewater, the main anammox-based processes are reviewed in this paper. It includes the partial nitritation/anammox process, the denitratation/anammox ( $\mathrm{PD} / \mathrm{A})$ process, the denitrifying anaerobic methane oxidation/anammox (DAMO/A) process, and more complex deuterogenic processes. These processes have made the breakthroughs in the application of the anammox technology, such as the combination of nitrification and PD/A process can achieve stability and reliability of nitrogen removal in the treatment of mainstream wastewater, the $\mathrm{PD} / \mathrm{A}$ process and the $\mathrm{DAMO} / \mathrm{A}$ have brought about further improvements in the total nitrogen removal efficiency of wastewater. The diversity of functional microbe characteristics under the specific condition indicate the wide application potential of anammox-based processes, and further exploration is necessary. A whole waste treatment system concept is proposed through the effective allocation of above mentioned processes, with the maximum recovery of energy and resources, and minimal environmental impact.

C The Author(s) 2021. This article is published with open access at link.springer.com and journal.hep. com.cn

\section{Introduction}

Over the past several decades, many researchers have engaged in the pursuit of the ultimate goal of the smooth

$凶$ Corresponding author

E-mail: gyokuyu.ri.a5@tohoku.ac.jp and reliable application of anammox process over a broader scope (Guo et al., 2020a; Fang et al., 2021; Fu et al., 2021). The theoretical knowledge obtained from the research work on this process is extensive, from the chemical perspective, microbial perspective, engineering perspective and process application perspective (Bi et al., 2020; Ding et al., 2021; Li et al., 2021; Qiu et al., 2021; Xu et al., 2021). In practice, many installations adopting 
anammox-based processes have been constructed and operated in an attempt to achieve a more effective treatment system in the wastewater treatment sectors. However, a review of related research indicates that most of the application cases have been limited to the treatment of sidestream wastewater, like biomass digestion effluent, landfill leachate, and the advantages of this process for sidestream wastewater have been clearly shown. However, significant challenges remain in the treatment of mainstream wastewater, with performance stability and quality the main challenge in actual application of this process (Chen et al., 2019). Therefore, the main challenge in developing the anammox process is in its actual application to the treatment of mainstream wastewater, and new ways to overcome the bottlenecks are being vigorously explored. Challenges remain in the sidestream wastewater treatment field using anammox-based processes as well: the long-startup time, the limited nitrogen removal efficiency (NRE) and the fragile resistance ability of microbes to external environment fluctuation are considered insurmountable barriers in the effective implementation of this process. To some extent, these problems are caused by such extrinsic factors as the difficulty of operation and control and complex feedback conditions (Guo et al., 2020c). There are, however, other intrinsic factors which need more attention, such as the low growth rate of anammox bacteria, the low anammox specific activity at low temperature, the easily inhibition of anammox bacteria at extreme environment.

It is vital to ensure the stable and reliable acquisition of both nitrite and ammonium, both of which are reactants in the anammox reaction in the anammox-based process. However, in actual applications, the nitrogen species in wastewater differ according to the source of the wastewater (Guo et al., 2020a). In practice, in the biomass digestion effluent and the landfill leachate, the main nitrogen species is ammonium, while in the fertilizer in runoff, and in explosive production wastewater, the main nitrogen species is nitrate. Therefore, it is important that the appropriate process is adopted to deal with the actual nitrogen species in the specific wastewater, and the influent must be pre-treated to supply the nitrite and ammonium with balance for the anammox reaction. A number of different combinations of anammox process and pretreatment processes have been developed: the partial nitritation (PN)/anammox (PN/A) process (F. Qian et al., 2018), the denitratation (PD)/anammox (PD/A) process ( $\mathrm{Si}$ et al., 2018), the denitrifying anaerobic methane oxidation (DAMO)/anammox (DAMO/A) process (Shi et al., 2013), and the dissimilatory nitrate reduction by anammox bacteria (DNRA)/anammox process (Castro-Barros et al., 2017).

As biological methods, the anammox-based processes are closely related with the function of microbes, like anammox bacteria, ammonium oxidizing bacteria (AOB), denitratation bacteria (DB), and DAMO archaea. The specific metabolism characteristics of the different microbe species need to be properly utilized in anammox-based processes because functional microbes are crucial for the successful realization of nitrogen removal. The temperature, $\mathrm{pH}$, substrate concentration, salinity, and presence of hazardous substances exerts an effect on the microbes to some extent. In actual applications, unless the conditions are idea, the function of microbes will be reshaped, disturbing the whole nitrogen removal route, and compromising nitrogen removal (Guo et al., 2020c). The combination of at least two kinds of functional microbes in anammox-based processes constrains the reactor environment. Therefore, the metabolism characteristics of each functional microbe species need to be well-understood to optimize the process and successfully conduct the operation of the related installations in actual applications.

In this review, the major anammox-based processes in actual application are reviewed, and the microbe information are summarized to provide a thorough guide to the mechanisms in each process in the actual applications. Finally, a novel integrated system concept for waste treatment is proposed to maximize energy and resource recovery and minimize the detrimental effect of waste treatment on the environment.

\section{The main anammox-based processes}

The pre-treatment processes of actual wastewater can be divided into different categories in anammox applications. This can be done based on a number of different considerations. From the nitrite supply route perspective, the pre-treatment processes can be separated into the nitritation process and PD process (Ma et al., 2020a). From the electron-donor perspective, the pre-treatment processes can be separated into the nitritation process, the organic matter-based PD process (Ma et al., 2017), the thiosulfatebased PD process (J. Qian et al., 2018; Deng et al., 2019) and the methane-based DAMO process (Shi et al., 2013). With the combination of anammox and these above mentioned pre-treatment processes, many anammoxbased processes have been developed toward actual application.

Based on the core mechanism and actual feasibility, three comprehensive and practical anammox-based processes have garnered most of the research attention: the $\mathrm{PN} / \mathrm{A}$ process (Chen et al., 2019), the $\mathrm{PD} / \mathrm{A}$ process (Ma et al., 2017; Zhou et al., 2020), and the DAMO/A process (Shi et al., 2013; T. Liu et al., 2019; Liu et al., 2020). The nitrogen removal pathway of these processes are shown in Fig. 1. Details of these processes are shown in Table 1 for comparison purposes. Among these three processes, it can be seen that the PN/A process is the most presentative and practical since, for different types of actual wastewater, the largest share of nitrogen species is the ammonium (Guo et al., 2020a). Since the performance of the $\mathrm{PD} / \mathrm{A}$ process 


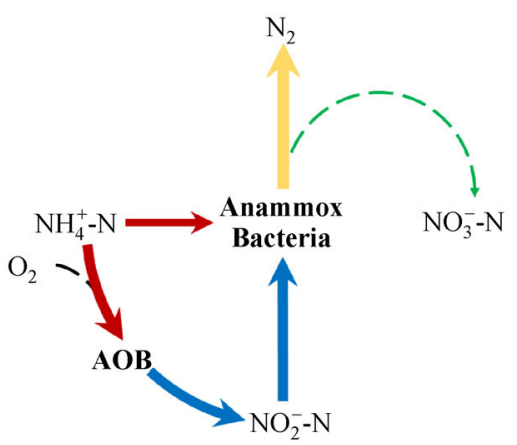

PN/A process

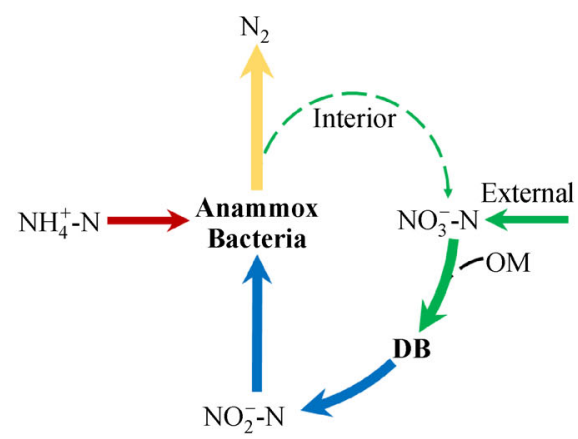

PD/A process

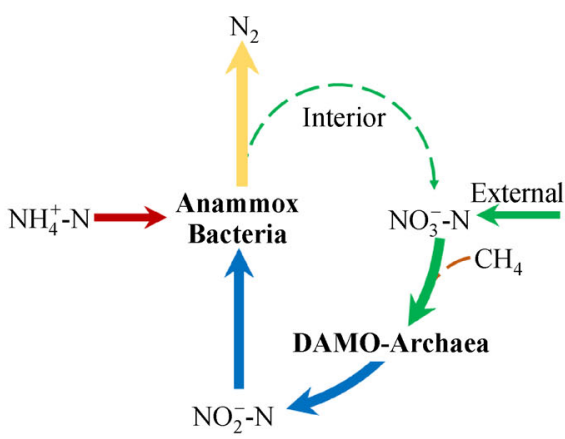

DAMO/A process

Fig. 1 The nitrogen removal pathway of three anammox-based processes.

Table 1 Characteristics of the main anammox-based processes

\begin{tabular}{|c|c|c|c|c|c|c|}
\hline Process & Substrate & Reaction & Microbe & Environment & Theoretical NRE & Products \\
\hline$\overline{\mathrm{PN} / \mathrm{A}}$ & $\mathrm{O}_{2} \mathrm{NH}_{4}^{+}-\mathrm{N}$ & Nitritation Anammox & AOB Anammox bacteria & Aerobic Anaerobic & $\approx 90 \%$ & $\mathrm{~N}_{2} \mathrm{NO}_{3}^{-}-\mathrm{N}$ \\
\hline $\mathrm{DN} / \mathrm{A}$ & $\mathrm{BOD} \mathrm{NO}{ }^{-}-\mathrm{N} \mathrm{NH}_{4}{ }^{+}-\mathrm{N}$ & Denitratation Anammox & DB Anammox bacteria & Anaerobic & $\approx 100 \%$ & $\mathrm{~N}_{2} \mathrm{CO}_{2}$ \\
\hline $\mathrm{DAMO} / \mathrm{A}$ & $\mathrm{CH}_{4} \mathrm{NO}_{3}^{-}-\mathrm{N} \mathrm{NH}_{4}^{+}-\mathrm{N}$ & DAMO Anammox & DAMO-archaea Anammox bacteria & Anaerobic & $\approx 100 \%$ & $\mathrm{~N}_{2} \mathrm{CO}_{2}$ \\
\hline
\end{tabular}

and the DAMO/A process is desirable in improving NRE, in recent years, these two processes are increasingly drawing more attention.

\subsection{PN/A process}

The PN/A process is the process most investigated at the laboratory-scale and pilot-scale, and even at the full-scale. The majority of the research is on the treatment of sidestream wastewater, like digestion effluent, landfill leachate, and specific types of industrial effluent. For a long time, this process was considered impractical for the treatment of mainstream wastewater due to the low NRE and the instability of the performance (Cao et al., 2017; Chen et al., 2019). In recent years, more and more effort has been focused on improving the application of this process in the treatment of mainstream wastewater. As shown in Fig. 2, in this process, two kinds of bacteria are involved in the PN/A process: the AOB and anammox bacteria (Wang et al., 2021). In the case of the influent ammonium, part of which is oxidized to nitrite through the nitritation process, this nitrite and the residual ammonium are converted into nitrogen gas and a little nitrate by the anammox process.

Since there are two distinct biological reactions involved, the installations in actual applications can be

(a) Two-stage PN/A process

One pass mode:

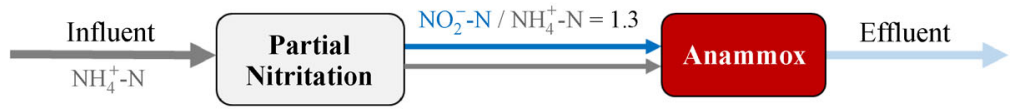

By-pass mode:

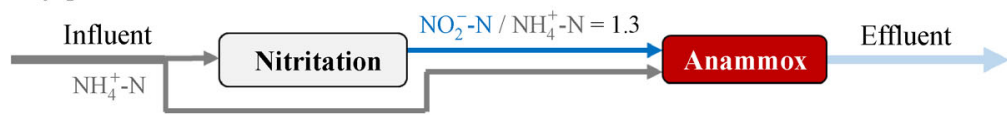

(b) One-stage PN/A process

$\underset{\mathrm{NH}_{4}^{+}-\mathrm{N}}{\frac{\text { Partial nitritation / anammox }}{\mathrm{NO}_{2}^{-}-\mathrm{N} / \mathrm{NH}_{4}^{+}-\mathrm{N}=1.3} \text { Effluent }}$

Fig. 2 The actual configuration of the PN/A process. 
divided into the two-stage configuration and the one-stage configuration (Guo et al., 2020a). In the two-stage configuration, the nitritation step and anammox step occur in two sequential reactors, as shown in Fig. 2a. In the two-stage configuration, according to whether there is a bypass for the influent, the two-stage configuration can further be divided into a one-pass configuration and a bypass configuration, as shown in Fig. 2a. In the one-stage mode, the nitritation step and anammox step occur in a single reactor, as shown in Fig. $2 \mathrm{~b}$.

Nitritation is conducted by autotrophic AOB with the reaction, expressed by equation (1) (Antwi et al., 2020). The anammox reaction is conducted by autotrophic bacteria, and four anammox reactions have been proposed (Guo et al., 2020a), as shown in equation (2), equation (3), equation (4) and equation (5):

Nitritation reaction:

$$
\begin{aligned}
& \mathrm{NH}_{4}+1.238 \mathrm{O}_{2}+0.04 \mathrm{HCO}_{3}^{-}+0.161 \mathrm{CO}_{2} \\
\rightarrow & 0.96 \mathrm{NO}_{2}^{-}+0.04 \mathrm{C}_{5} \mathrm{H}_{7} \mathrm{NO}_{2}+0.919 \mathrm{H}_{2} \mathrm{O} \\
+ & 1.919 \mathrm{H}^{+}
\end{aligned}
$$

anammox reaction:

$$
\begin{aligned}
& \mathrm{NH}_{4}^{+}+1.32 \mathrm{NO}_{2}^{-}+0.066 \mathrm{HCO}_{3}^{-}+0.13 \mathrm{H}^{+} \\
\rightarrow & 1.02 \mathrm{~N}_{2}+0.26 \mathrm{NO}_{3}^{-}+0.066 \mathrm{CH}_{2} \mathrm{O}_{0.5} \mathrm{~N}_{0.15} \\
& +2.03 \mathrm{H}_{2} \mathrm{O} \\
& 1 \mathrm{NH}_{4}^{+}+1.146 \mathrm{NO}_{2}^{-}+0.071 \mathrm{HCO}_{3}^{-}+0.057 \mathrm{H}^{+} \\
\rightarrow & 0.986 \mathrm{~N}_{2}+0.161 \mathrm{NO}_{3}^{-}+0.071 \mathrm{CH}_{1.74} \mathrm{O}_{0.31} \mathrm{~N}_{0.20} \\
+ & 2.002 \mathrm{H}_{2} \mathrm{O} \\
& 1 \mathrm{NH}_{4}^{+}+1.133 \mathrm{NO}_{2}^{-}+0.092 \mathrm{HCO}_{3}^{-}+0.038 \mathrm{H}^{+} \\
\rightarrow & 0.980 \mathrm{~N}_{2}+0.161 \mathrm{NO}_{3}^{-}+0.092 \mathrm{CH}_{2.26} \mathrm{O}_{1.07} \mathrm{~N}_{0.14} \\
+ & 1.961 \mathrm{H}_{2} \mathrm{O}\left(\mathrm{NLR}^{-}=5.0 \mathrm{~kg} / \mathrm{m}^{3} / \mathrm{d}\right)
\end{aligned}
$$

$$
\begin{aligned}
& 1 \mathrm{NH}_{4}^{+}+1.300 \mathrm{NO}_{2}^{-}+0.121 \mathrm{HCO}_{3}^{-}+0.367 \mathrm{H}^{+} \\
& \rightarrow 1.020 \mathrm{~N}_{2}+0.242 \mathrm{NO}_{3}^{-}+0.121 \mathrm{CH}_{1.74} \mathrm{O}_{0.81} \mathrm{~N}_{0.15} \\
& +2.139 \mathrm{H}_{2} \mathrm{O}\left(\mathrm{NLR}=50.0 \mathrm{~kg} / \mathrm{m}^{3} / \mathrm{d}\right)
\end{aligned}
$$

In the one-stage PN/A process, the $\mathrm{AOB}$ and anammox bacteria experience the same growth conditions, like temperature, $\mathrm{pH}$, free ammonium (FA), and free nitrite acid (FNA). Therefore, the maximum overlap of the suitable growth environment of each bacteria is crucial for the successful and stable operation of this kind of configuration. In reverse, in the two-stage PN/A process, each kind of bacteria has its own growth environment. As such, it is feasible to create the most suitable environment for each type of bacteria, which is an effective way to maximize their ability in the nitrogen removal. However, from the achieved NRR by each process based on the previous research, as shown in Table 2, the one-stage PN/A process still have the efficiency advantage in the actual application (Guo et al., 2020a).

In actual applications, mainstream wastewater occupy the huge share of the nitrogen pollutants by the whole society. In wastewater treatment plant (WWTP), the adoption of the anammox-based process can realize the prominent reduction of the energy consumption (X. Li et al., 2017; Du et al., 2019). The granule anammox sludge can maximize the utilization of reactor volume and has the more surface area, which has the distinct advantages, like high surface area, than that of the biofilm sludge (Guo et

\begin{tabular}{|c|c|c|c|c|c|c|c|c|c|c|}
\hline Reactor & Configuration & Scale & Temp $\left({ }^{\circ} \mathrm{C}\right)$ & $\mathrm{pH}$ & Wastewater & $\mathrm{NH}_{4}{ }^{+}-\mathrm{N}(\mathrm{mg} / \mathrm{L}$ & HRT (h) & $\operatorname{NRR}\left(\mathrm{kg} / \mathrm{m}^{3} / \mathrm{d}\right)$ & NRE (\%) & Reference \\
\hline$\overline{\text { ALR }}$ & One-stage & Laboratory & 25 & $7.6 \pm 0.3$ & Mainstream & 50 & 2 & 0.72 & 71.8 & Chen et al., 2019 \\
\hline \multirow{2}{*}{ ALR } & \multirow{2}{*}{ One-stage } & \multirow{2}{*}{ Laboratory } & \multirow{2}{*}{25} & \multirow{2}{*}{$7.8-8.2$} & \multirow{2}{*}{ Mainstream } & 63 & 1 & 1.28 & 78.7 & \multirow{2}{*}{ Guo et al., 2021} \\
\hline & & & & & & 42 & 1 & 0.66 & 63.2 & \\
\hline ALR & One-stage & Laboratory & 30 & - & Sidestream & 448.8 & 2 & 3.9 & 73 & Wang et al., 2017 \\
\hline ALR & One-stage & Laboratory & 30 & 7.7 & Sidestream & 304 & 1.5 & $>3.9$ & $>80$ & Qian et al., 2018 \\
\hline ALR & Two-stage & Pilot & 30 & - & Sidestream & 1150 & 48 & 0.6 & 72 & Wang et al., 2017 \\
\hline $\mathrm{MBR}+\mathrm{UASB}$ & Two-stage & Laboratory & $24-32$ & $7.5-8.5$ & Sidestream & $900-1500$ & - & $0.77-2.16$ & $>80$ & Li et al., 2017 \\
\hline
\end{tabular}
al., 2021). However, the size of granule is too small or too big, still causing the negative effect, like the sludge washout or the decrease of the substance transfer effect (Tang et al., 2011; Tan et al., 2020). The washout was caused by the too short HRT or the gas accumulation in sludge due to the improper operation. The decrease of substance transfer effect was caused by the too big size of granule sludge. Thus, cultivating the granule sludge with small size and well settling ability is the crucial. Thus, granule sludge is the hopeful choice in the anammox application in the main-stream wastewater treatment. In mainstream wastewater treatment, the short HRT is very crucial to the nitrogen efficiency. Under the low HRT, the

Table 2 The highest NRRs reported in PN/A process research under different condition

MBR: membrane biological reactor. 
substance transfer is the crucial, which can only be well realized by the granule sludge. For the application of granule sludge in mainstream wastewater treatment, there have been several breakthroughs in recent years at the laboratory-scale, as shown in Table 2 . In the treatment of $50 \mathrm{mg} / \mathrm{L}$ ammonium wastewater with a micro granulebased PN/A reactor, the long-term operation results showed that NRR of $0.72 \mathrm{~kg} / \mathrm{m}^{3} / \mathrm{d}$ were obtained under a relatively short hydraulic retention time (HRT) of $2 \mathrm{~h}$ (Chen et al., 2019). In another work, by cultivating a concentrated, highly dispersive granule sludge with good settleability in a one-stage PN/A-hydroxyapatite (HAP) reactor, at an HRT of about $1.0 \mathrm{~h}$ and influent ammonium concentration of $63.0 \mathrm{mg} / \mathrm{L}$, the average nitrogen removal rate (NRR) was $1.28 \mathrm{~kg} / \mathrm{m}^{3} / \mathrm{d}$, which far exceeds that reported in similar studies (Guo et al., 2021). The impressive performance of these processes achieved with synthetic wastewater demands further verification in the actual treatment of mainstream wastewater.

In the application of the PN/A process to the treatment of both sidestream wastewater and mainstream wastewater, the non-negligible problem is that the maximum NRE of this process is limited by the nitrate production in the anammox reaction (Guo et al., 2020a). We know that at least $11 \%$ of influent ammonium is converted to nitrate at the ideal state. With the influent ammonium concentration of several hundred or several thousand $\mathrm{mg} / \mathrm{L}$, the effluent nitrate concentration still can reach dozens or hundreds $\mathrm{mg} / \mathrm{L}$ (Guo et al., 2020a). This is not negligible. Because actual mainstream wastewater has a low ammonium concentration, the residual nitrate in effluent can still meet the discharge standard. However, in the case of the sidestream wastewater, the nitrate produced by anammox reaction cannot be ignored, and the further removal of this nitrogen species is necessary. To overcome this, the following extension process is proposed.

\section{$2.2 \mathrm{PD} / \mathrm{A}$ process}

In the treatment of nitrate wastewater through the anammox process, the PD process is a cost-saving process for nitrite supply (Chen et al., 2021). The traditional denitrification process requires that the organic carbon source supply has a theoretic $\mathrm{COD} /$ nitrate ratio of at least 2.86. However, with the PD process, the required $\mathrm{COD} /$ nitrate ratio is just 1.14. It represents a COD saving of about $60 \%$. PD is conducted by autotrophic bacteria according to the reaction shown in equation (6) (Ma et al., 2020a).

$$
\begin{aligned}
& 0.048 \mathrm{NH}_{4}^{+}+\mathrm{NO}_{3}^{+}+0.37 \mathrm{CH}_{3} \mathrm{COO}^{-}+0.32 \mathrm{H}^{+} \\
\rightarrow & \mathrm{NO}_{2}^{-}+0.048 \mathrm{C}_{5} \mathrm{H}_{7} \mathrm{NO}_{2}+0.64 \mathrm{H}_{2} \mathrm{O}+0.5 \mathrm{CO}_{2}
\end{aligned}
$$

Developments in the PD process are suitable for three applications. One is suited for the treatment of nitrate wastewater. In the event that both ammonium wastewater and nitrate wastewater are in one location, the joint treatment of two kinds of wastewater seems feasible. The nitrate in the wastewater can be converted into nitrite, then the nitrite wastewater and ammonium wastewater can finally converge to the anammox process, and the nitrogen species can be removed, as shown in Fig. 3a. This joint process is referred to as the PD/A process (Deng et al., 2019; Yang et al., 2020). The application of this process is limited to situations where certain conditions are met: one is the ability to secure access to both nitrate wastewater and ammonium wastewater in one location; and the other is a balance between nitrite input and ammonium input.

Another development is suited to the treatment of nitrate effluent from the PN/A process reactor in the treatment of sidestream wastewater. The PD process can convert this nitrate into nitrite, which can participate in the anammox reaction again for complete removal according to the specific process design shown in Fig. 3b. In this situation, there are three biological reactions involved in nitrogen removal during the whole process: $\mathrm{PN}$, anammox, and PD. This process is referred to as the PN/A-denitratation (PN/ A-PD) process. In a study of the PN/A-PD process, $80 \%$ of the nitrate in the effluent of anammox was converted to nitrite, and a maximum NRE of $94.06 \%$ was obtained with the total nitrogen (TN) in the effluent at $10.98 \mathrm{mg} / \mathrm{L}$ on average (Du et al., 2015). The discussion above leads to the conclusion that the optimal process order for the treatment of sidestream wastewater treatment to achieve the ideal NRE is PN/A-PD $>$ PN/A > TND.

The third development is suited to the treatment of mainstream wastewater. The application of the PN/A process to the treatment of mainstream wastewater still faces a bottleneck due to its unstable removal performance, the difficulty of AOB inhibition, and low temperature. In recent years, a novel approach proposed is the complete ("complete" means the complete conversion of ammonium to nitrate) nitrification (CN)-PD/A (CN-PD/A) process shown in Fig. 3c (Ma et al., 2017). In this process, part of the influent is introduced into the nitrification reactor, where all the ammonium is completely oxidized to nitrate. Then, this part of flow and another part of influent are introduced into the post-set or pre-set $\mathrm{PD} / \mathrm{A}$ reactor. In $\mathrm{PD} /$ A reactor, the nitrate is stably and reliably converted to nitrite. Meanwhile, the produced nitrite and the ammonium are converted to nitrogen gas by anammox bacteria. Then, nitrate with a low concentration is produced again. In this process, the difficulty of the PN/A process in the treatment of mainstream wastewater due to unavoidable nitriteoxidizing bacteria (NOB) inhibition and low NRR is avoided, and the nitrogen removal performance is excellent. In a CN-PD/A process for the treatment of mainstream wastewater, an NRE of $80 \pm 4 \%$ for the influent with a low $\mathrm{COD} / \mathrm{NH}_{4}{ }^{+} \mathrm{N}$ ratio of 2.6 and a $\mathrm{TN}$ concentration of $60.5 \mathrm{mg} / \mathrm{L}$ was achieved (Ma et al., 2017).

Based on the nitrification equation (7), denitrification 
(a) High strength wastewater

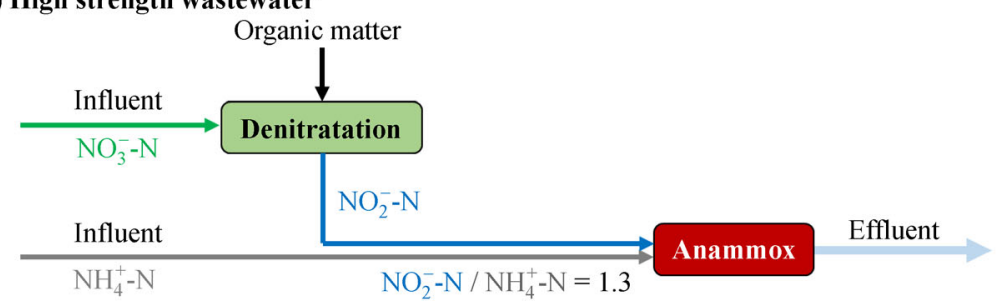

(b) High strength wastewater

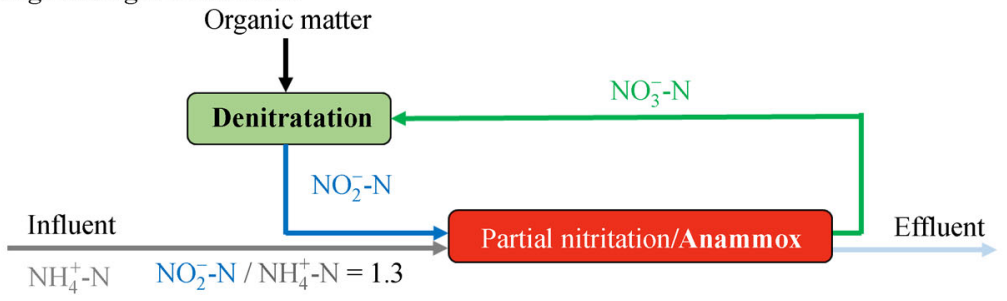

(c) Low ammonium wastewater

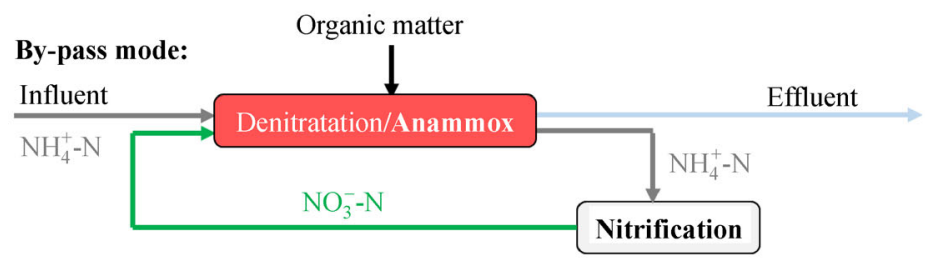

Fig. 3 The actual configuration of the PD/A-based process.

equation (8), the PN equation, the PD equation (Ma et al., 2020a),

$$
\begin{gathered}
\mathrm{NH}_{4}^{+}+0.0396 \mathrm{NO}_{2}^{-}+1.666 \mathrm{O}_{2}+0.0495 \mathrm{HCO}_{3}^{-} \\
+0.199 \mathrm{CO}_{2}+0.01 \mathrm{H}_{2} \mathrm{O} \rightarrow 0.0495 \mathrm{C}_{5} \mathrm{H}_{7} \mathrm{NO}_{2} \\
+0.910 \mathrm{H}_{2} \mathrm{O}+1.9 \mathrm{H}^{+}+0.99 \mathrm{NO}_{3}^{-} \\
\mathrm{NO}_{3}^{+}+0.168 \mathrm{NH}_{4}^{+}+1.05 \mathrm{CH}_{3} \mathrm{COO}^{-}+1.89 \mathrm{H}^{+} \\
\rightarrow 0.168 \mathrm{C}_{5} \mathrm{H}_{7} \mathrm{NO}_{2}+0.5 \mathrm{~N}_{2}+2.26 \mathrm{H}_{2} \mathrm{O}+1.25 \mathrm{CO}_{2}
\end{gathered}
$$

a comparison of TND process, the PN/A process and the $\mathrm{CN}-\mathrm{PD} / \mathrm{A}$ process in mainstream wastewater treatment is shown in Table 3. From table, it can be seen that although the TND process has very strong operability, the PN/A and $\mathrm{CN}-\mathrm{PD} / \mathrm{A}$ processes have obvious advantages with regard to the reduction of oxygen consumption, carbon source consumption, and the reduced sludge production. Despite the higher oxygen consumption of the CN-PD/A (57\%), the carbon source requirements $(22.8 \%)$, and sludge production (39.31\%) than the PN/A process, this process has distinct advantages over the TND, and the operability is strong. Since the actual application of the PN/A process in the treatment of mainstream wastewater still faces difficulty due to unstable performance, the growth of NOB, especially at low temperatures, the second best performer, the $\mathrm{CN}-\mathrm{PD} / \mathrm{A}$ process, is recommended. The nitrogen removal performance of the CN-PD/A process has been reported to be constant (Ma et al., 2020b). From the above, it can be concluded that in the treatment of mainstream wastewater, the process optimal order is $\mathrm{CN}-\mathrm{PD} / \mathrm{A}>\mathrm{PN} / \mathrm{A}$ $>$ TND.

\section{$2.3 \mathrm{DAMO} / \mathrm{A}$ process}

There are basically two kinds of DAMO microbes $(\mathrm{Fu}$ et al., 2017a): the DAMO-archaea, which convert the nitrate to the nitrite, as shown in equation (9), and the DAMO-bacteria, which concert the nitrite to nitrogen gas, as shown in equation (10). In an ideal DAMO/A-based

Table 3 The three processes for mainstream wastewater treatment

\begin{tabular}{lccccc}
\hline Process & Oxygen consumption & Carbon source consumption & Sludge production & Operability \\
\hline TND & $100 \%$ & $100 \%$ & $100 \%$ & Very strong & \\
PN/A & $42.3 \%$ & 0 & $20.82 \%$ & Weak & Strong \\
CN-PN/A & $57 \%$ & $22.8 \%$ & $39.31 \%$ & \\
\hline
\end{tabular}


process, only the DAMO-archaea and anammox activity is expected for methane saving. However, in actual DAMO/ A process, because there is always DAMO-bacteria in the reactor besides the DAMO-archaea and anammox bacteria, a portion of the nitrogen removed can be attributed to the DAMO-bacteria (Xie et al., 2017).

$$
\begin{gathered}
\mathrm{NO}_{3}^{-}+0.25 \mathrm{CH}_{4} \rightarrow \mathrm{NO}_{2}^{-}+0.25 \mathrm{CO}_{2}+0.5 \mathrm{H}_{2} \mathrm{O} \\
\mathrm{NO}_{2}^{-}+0.375 \mathrm{CH}_{4}+\mathrm{H}^{+} \\
\rightarrow 0.5 \mathrm{~N}_{2}+0.375 \mathrm{CO}_{2}+1.25 \mathrm{H}_{2} \mathrm{O}
\end{gathered}
$$

For the application of the DAMO/A process, methane transportation is the most important step due to the low dissolubility of methane and the unique environment requirement of DAMO microbes. The limitation of methane transfer affects the DAMO/A-based process more notably than nitrogen transfer. Two ways to supply methane to the DAMO/A-based process have been shown: one is the use of a hollow fiber membrane (Shi et al., 2013; Ding et al., 2017), which facilitates the consumption of the methane by the attached biofilm, and the second is by dissolving the methane into the influent (Fan et al., 2019). In practice, the anaerobic fermentation produces methane with the gas phase and the liquid phase. While the methane in the gas phase can be easily collected and purified, the dissolved methane is difficult to recover, especially at lower temperatures. Also, the slow release of the dissolved methane into the environment contributes to the greenhouse effect and makes it undesirable. This suggests that the DAMO/A-based process is capable of resolving both the ammonium removal and methane emission problems in the anaerobic fermentation effluent (Fu et al., 2017a).

The typical reports about nitrogen removal performance of DAMO/A process is shown in Table 4. Initially, the hollow fiber membrane biological reactor is suitable for enriching DAMO microorganisms (Ding et al., 2017). In the membrane biological fiber reactor (MBfR), it was reported that the biofilms formed on fibers surface included two layers: the inner layer was thin and dominated by DAMO-bacteria and anammox bacteria, while the outer layer was thick made up of granules 100-200 $\mu \mathrm{m}$ in diameter and dominated by DAMO-archaea (Fu et al., 2017a). The high performance of NRR of $16.53 \mathrm{~kg} / \mathrm{m}^{3} / \mathrm{d}$ with satisfactory effluent quality (similar to $8 \mathrm{mg} / \mathrm{L}$ ) makes the practical application of DAMO/A in wastewater treatment promising (Fan et al., 2019). It has been recently shown that the granular sludge can also be successfully applied for nitrogen removal from synthetic partial nitritation effluent (Fan et al., 2019). It has been revealed that a layered structure is formed in the granular sludge with anammox bacteria in the outer layer and DAMO microorganisms in the inner layer, and a high NRR of $1.0 \mathrm{~kg} / \mathrm{m}^{3} / \mathrm{d}$ is achieved from synthetic sidestream wastewater (Liu et al., 2021).

There are several possible applications of the DAMO/A process. Like the $\mathrm{PD} / \mathrm{A}$ process, the $\mathrm{DAMO} / \mathrm{A}$ process is suited for the treatment of nitrate wastewater and ammonium wastewater, as shown in Fig. 4a. It can also be applied to the two-stage $\mathrm{PN}$ and $\mathrm{DAMO} / \mathrm{A}$ (PNDAMO/A) process (Nie et al., 2019; Liu et al., 2021, 2020), as shown in Fig. 4b. This design is based on the DAMO microbes and the anammox bacteria, both of which require an anaerobic environment (Nie et al., 2019). As shown in Table 4, in an MBfR reactor, with biofilms consisting of a coculture of DAMO and anammox microorganisms, a NRR of $0.68 \mathrm{~kg} / \mathrm{m}^{3} / \mathrm{d}$ was achieved, indicating that the nitrate reduction rate achieved by the DAMO process can be high enough to remove the nitrate produced by the anammox process, therefore enabling complete nitrogen removal from wastewater (Cai et al., 2015). In a two-stage PN-DAMO/A process, a high performance of NRR, at $2.5 \mathrm{~kg} / \mathrm{m}^{3} / \mathrm{d}$, was reported within 200 days operation, indicating the potential of the DAMO/ A process in wastewater treatment applications (Nie et al., 2019). In another two-stage PN-DAMO/A process, with an HRT of 1 day, the process achieved an NRR of over $1 \mathrm{~kg} / \mathrm{m}^{3} / \mathrm{d}$, and nitrite and ammonium removal rates of $0.56 \mathrm{~kg} / \mathrm{m}^{3} / \mathrm{d}$ and $0.47 \mathrm{~kg} / \mathrm{m}^{3} / \mathrm{d}$, respectively, with no nitrate accumulation (Xie et al., 2017). An effluent with $3 \mathrm{mg}$ TN/L was achieved simultaneously by integrating anammox and DAMO reactions in mainstream wastewater treatment (Xie et al., 2018). A stable NRR of $0.13 \mathrm{~kg} / \mathrm{m}^{3} / \mathrm{d}$,

Table 4 The typical reports about nitrogen removal performance of DAMO/A process

\begin{tabular}{lcccccccccc}
\hline Process & Configuration & Scale & Temp $\left({ }^{\circ} \mathrm{C}\right)$ & $\mathrm{pH}$ & Wastewater & $\mathrm{TN}(\mathrm{mg} / \mathrm{L})$ & HRT $(\mathrm{h})$ & $\mathrm{NRR}\left(\mathrm{kg} / \mathrm{m}^{3} / \mathrm{d}\right)$ & NRE $(\%)$ & Reference \\
\hline DAMO/A & MGSR & Laboratory & $35 \pm 1$ & $7.8-8.0$ & Sidestream & 1000 & 1.44 & 16.53 & 99.2 & Fan et al., 2019 \\
DAMO/A & Granule & Laboratory & $30 \pm 0.5$ & $7.0 \pm 0.2$ & Sidestream & 1050 & 24 & 1.0 & 94.8 & Liu et al., 2021 \\
DAMO/A & MAMBR & Laboratory & $35 \pm 1.0$ & $7.0-7.5$ & Sidestream & 5000 & 48 & 2.5 & $>99.9$ & Nie et al., 2019 \\
DAMO/A & MBfR & Laboratory & - & $7.0-8.0$ & Sidestream & 1030 & 24 & 1.0 & $>99.9$ & Xie et al., 2017 \\
DAMO/A & MBfR & Laboratory & - & $7.0 \pm 0.5$ & Mainstream & 51.5 & 4 & 0.28 & 93.3 & Xie et al., 2018 \\
DAMO/A & MBfR & Laboratory & 10 & $7.0 \pm 0.5$ & Mainstream & 51.5 & 9 & 0.13 & $90-94$ & Liu et al., 2020 \\
PN-DAMO/A & MBfR & Laboratory & $30 \pm 1$ & $7.0 \pm 0.5$ & Sidestream & 1030 & 16 & 1.5 & 98 & Liu et al., 2019 \\
\hline
\end{tabular}

MGSR: Membrane Granular Sludge Reactor; MAMBR: Membrane Aerated Membrane Bioreactor. 
together with a high-level effluent quality $(\mathrm{TN}<$ $5.0 \mathrm{mg} / \mathrm{L}$ ) was also achieved in a laboratory-scale upflow MBfR by the DAMO/A process at a temperature as low as $10^{\circ} \mathrm{C}$ (Liu et al., 2020). The third process, named the onestage PN-DAMO/A, integrates PN, anammox and DAMO in a single MBfR, as shown in Fig. 4c. With sidestream wastewater feeding, the proposed one-stage PN-DAMO/A process achieved an average NRE of $98 \%$ and a NRR of $1.5 \mathrm{~kg} / \mathrm{m}^{3} / \mathrm{d}$ (T. Liu et al., 2019).

There are several issues in the wastewater treatment adopting the DAMO process. First, methane is characterized with the inflammability and low aqueous solubility. In laboratory-scale studies, the increased energy for sparging methane to the reactor, the additional cost in the methane transportation system and the release of methane in actual applications are the drawbacks (Shi et al., 2013). Second, anammox bacteria, DAMO-bacteria and DAMO-archaea are involved in nitrogen removal in the DAMO processes. The control of DAMO-bacteria is necessary to save methane. It has been reported that competency of DAMO-bacteria is lower in the presence of nitrite and ammonium than anammox bacteria (Stultiens et al., 2019). Therefore, operation parameter controls may need to be adopted to control DAMO-bacteria.

\section{The characteristics of functional microbe species}

\subsection{Anammox species}

To date, six anammox genera and at least 24 species have been detected, as shown in Table 5. It should be noted that few investigations have been focused on identifying most of these species, and that the environments have also been limited. For instance, species moscowii has only been reported once, and most species of the genus Scalindua have only been found in environments with high salinity. The anammox species detected in laboratory-scale reactors and WWTPs are mainly from the genus of Anammoxoglobus, Brocadia, Jettenia, and Kuenenia (Song et al., 2020). As each species has a defined but as yet unknown niche, two different anammox species can rarely be found in the same natural location (Kartal et al., 2007b). In addition, the growth and optimal temperature (Tomaszewski et al., 2017), salinity (Gonzalez-Silva et al., 2017), nitrogen loading rate (NLR) (Zhang et al., 2017), HRT (Park et al., 2015), disproportionate substrate concentration (Qiao et al., 2017), and volatile fat acids (VFAs) (Nejidat et al., 2018) are crucial parameters which

(a) DAMO/anammox process

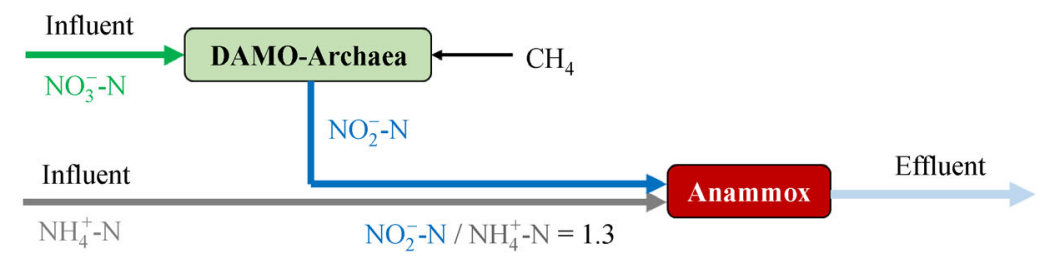

(b) Two-stage partial nitritation and DAMO/anammox process

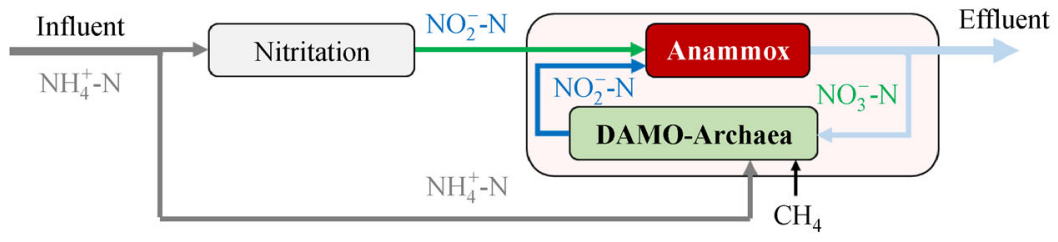

(c) One-stage partial nitritation and DAMO/anammox process

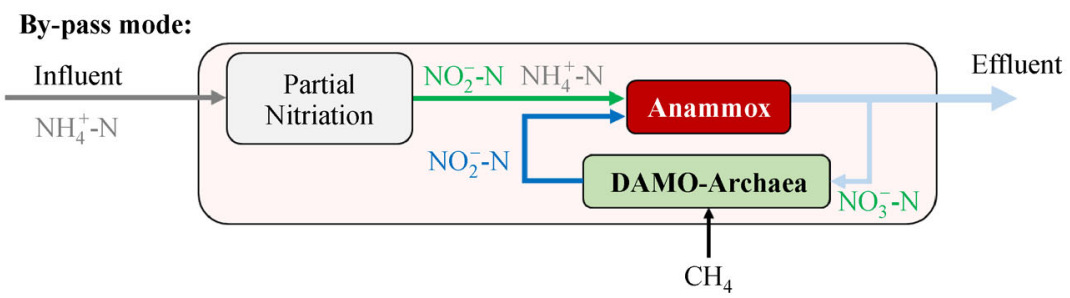

Fig. 4 The actual configuration of the DAMO/A-based process. 
Table 5 The reported anammox species and their main features

\begin{tabular}{|c|c|c|c|c|}
\hline \multirow{2}{*}{ Genus } & \multirow{2}{*}{ Species } & \multirow{2}{*}{$\mu_{\max }\left(\mathrm{h}^{-1}\right) / \mathrm{DB}(\mathrm{d})$} & Tolerance environment & \multirow{2}{*}{ Main characteristics and preferred habitat } \\
\hline & & & Temp. $\left({ }^{\circ} \mathrm{C}\right) / \mathrm{pH}$ & \\
\hline$\overline{\text { Anammoxoglobus }}$ & propionicus & n.d & $33 / 7-7.3$ & $\begin{array}{l}\text { Out-compete other anammox bacteria and heterotrophic denitrifiers for } \\
\text { the oxidation of propionate; Dominant in SNAD process. }\end{array}$ \\
\hline \multirow[t]{6}{*}{ Brocadia } & anammoxidans & $0.0027 /$ n.d & $20-52 / 6.7-8.3$ & The predominant species in low temperature mainstream. \\
\hline & fulgida & n.d & $10-52 / 7.2-8.3$ & $\begin{array}{l}\text { Strong autofluorescence; Out-competed other anammox bacteria in the } \\
\text { presence of acetate; Capable of organotrophic nitrate reduction; Become } \\
\text { worst at salinity; Survives with IC deficit; Tolerates low temperature until } \\
\qquad 10^{\circ} \mathrm{C} \text {. }\end{array}$ \\
\hline & sinica & $0.33 / 2.1$ & $25-45 / 6.5-8.8$ & $\begin{array}{l}\text { Dominated at high NLRs; The capacity to oxidize the VFAs; Good } \\
\text { tolerance to salinity, low temperature, phenol and thiocyanate; Superior } \\
\text { aggregation ability, better biomass retention as granules and conse- } \\
\text { quently stable performance. }\end{array}$ \\
\hline & caroliniensis & $<0.005 /$ n.d & $30 / 6.8-7.6$ & Enriched in nitrite shunt process. \\
\hline & sapporoensis & $0.0082 / 3.5$ & $20-45$ & - \\
\hline & brasiliensis & n.d & n.d & $\begin{array}{l}\text { Raised significantly at low substrate concentration condition; Found in } \\
\text { activated sludge. }\end{array}$ \\
\hline \multirow[t]{3}{*}{ Jettenia } & asiatica & n.d & n.d & $\begin{array}{l}\text { Found in granular sludge; Can utilize VFAs as carbon sources; Higher } \\
\text { adaptability to propionate stress than acetate; Show tolerate to phenol; } \\
\text { Can adapt to low temperature; An alternative lifestyle to chemolithoau- } \\
\text { totrophy. }\end{array}$ \\
\hline & caeni & $0.18 / 3.9$ & $20-42.5 / 6.5-8.5$ & Found in membrane bioreactor; Dominated at low NLRs. \\
\hline & moscovienalis & $0.025 / 28$ & $20-45 / 8.0$ & Extensive intracellular membrane structures. \\
\hline Kuenenia & stuttgartiensis & $<0.004 /$ n.d & $25-52 / 6.5-9.0$ & $\begin{array}{l}\text { The common species in research; Good tolerance to salinity, higher } \\
\text { affinity for nitrite, low temperature; Has a protein surface layer as the } \\
\text { outermost layer of the cell. }\end{array}$ \\
\hline \multirow[t]{11}{*}{ Scalindua } & sorokinii & n.d & n.d & $\begin{array}{l}\text { Found from Black sea; Existed in high ammonium and low nitrite } \\
\text { conditions from Black Sea }\end{array}$ \\
\hline & richardsii & n.d & n.d & $\begin{array}{l}\text { Found from Black sea; Existed at high nitrite/nitrate and low ammonium } \\
\text { from Black Sea }\end{array}$ \\
\hline & brodae & n.d & n.d & Found from WWTPs; Existed in soil. \\
\hline & wagneri & n.d & n.d & $\begin{array}{l}\text { Found from WWTP; Comparable or even higher tolerances for high } \\
\qquad \mathrm{NO}_{2}-\mathrm{N} .\end{array}$ \\
\hline & arabica & n.d & n.d & Found from Arabian Sea. \\
\hline & pacifica & n.d & n.d & Found from Bohai Sea; Versatile life style. \\
\hline & profunda & $0.002 / \mathrm{n} . \mathrm{d}$ & $15-45 / 7-8$ & Cyanate use for anammox reaction. \\
\hline & sinooilfield & n.d & n.d & Tolerate High-Temperature in petroleum reservoirs. \\
\hline & rubra & n.d & n.d & Uses compatible solutes for osmoadaptation, found in Red Sea. \\
\hline & zhenghei & n.d & n.d & Found from South China Sea. \\
\hline & japonica & n.d & n.d & - \\
\hline Anammoximicrobium & moscowii & n.d & n.d & Enriched from river in Moscow. \\
\hline
\end{tabular}

determine the metabolism of each kind of anammox bacteria species. Also, some anammox bacteria species show strong adaptability to extreme environments. Therefore, it is likely that the niches of anammox bacteria are much broader than generally thought, which suggests they may be able to exert their specific roles in applications for the treatment of special wastewater. There are several categories of environment-specific species categories. They are discussed in the following section:

\subsubsection{The volatile fatty acids-specific species}

For some kinds of actual wastewater, such as digested effluent, VFAs are an unavoidable component (Guo et al., 2020a). In studies incorporating simultaneous PN/A and denitrification (SNAD), the dominant species in the adopted reactor was propionicus (Wen et al., 2017), which could out-compete other anammox bacteria, even heterotrophic denitrifiers, for the oxidation of propionate 
(Kartal et al., 2007b). In the presence of acetate, The species fulgida also out-competed other anammox bacteria to realize organotrophic nitrate reduction (Winkler et al., 2012). Species stuttgartiensis cells can conduct DNRA to reduce nitrate to ammonium via nitrite (Kartal et al., 2007a). The species fulgida performs the DNRA/anammox reaction at a high rate in the presence of VFAs (Castro-Barros et al., 2017). Besides, it has also been reported that the species sinica and species asiatica also could oxidize the VFAs (Shu et al., 2015).

\subsubsection{The temperature-specific species}

The species capable of tolerating specific temperatures are detailed in Table 5. The growth temperature and optimal temperature of different species of anammox varied (Tomaszewski et al., 2017). The activation energy of the anammox reaction is higher than that of wastewater. The change in the nitrogen removal performance of the anammox-based process was attributed to reduced enzyme activity. With long-term cultivation, the adaptation of anammox bacteria at low temperature has also been observed (Lotti et al., 2015). Especially, species sinica was shown to have good tolerance to low temperature (J. Li et al., 2018).

\subsubsection{The salinity-specific species}

In a natural saline environment with a salinity of $84 \mathrm{~g} / \mathrm{L}$, the activity of anammox bacteria was still observed (Yang et al., 2012). It was found that species sinica and species stuttgartiensis had good tolerance to salinity (GonzalezSilva et al., 2017; J. Li et al., 2018). As expected, the genus Scalindua showed strong tolerance to salinity. However, the utilization of genus Scalindua in WWTP was poor. More exploration is required for a better understanding of this.

\subsubsection{The NLR-specific species}

At high NLRs, the species sinica was found to be dominant (Zhang et al., 2017; Cho et al., 2018; Oshiki et al., 2018). However, at low NLRs, the species caeni was found to be dominant (Ma et al., 2017; Zhang et al., 2017).

\subsubsection{The substrate-specific species}

As known to all, in the operation of anammox reactor, with the external factors, like the fluctuations of substrate and the operation parameters, being resolved, the reminding crucial aspect is inhibition effect of anammox bacteria by FA or FNA, especially the FNA. For the fresh water experiment, the genus Brocadia and the genus Kuenenia is a focus. Based on the previous theory, the genus Brocadia is the R-strategy, while genus Kuenenia is the S-strategy. In earlier studies, there were some contradictions about this hypothesis (Tang et al., 2010). It should be noticed that it is the actual nitrite concentration in reactor that determine the selection of anammox species rather than the influent nitrite concentration. In recently years, this hypothesis were verified in many one-stage PNA reactor and anammox reactor (Chen et al., 2019; Guo et al., 2020c). Also, in our laboratory, in the long term operation of both pure anammox reactor and the one-stage PNA reactor, with the low nitrite strategy or the no nitrite accumulation strategy, the almost pure genus Kuenenia was selected.

In addition, large increases were reported in the species brasiliensis under limited substrate conditions (W. Li et al., 2017). Species stuttgartiensis is known to have higher affinity for nitrite (van der Star et al., 2008; Ren et al., 2016). It was reported that species sorokinii was found in high ammonium and low nitrite condition. In reverse, in high nitrite/nitrate and low ammonium condition, species richardsii was detected. The high nitrite condition is favorable for species wagneri (Yokota et al., 2018).

\subsubsection{Hazardous substance-specific species}

It has been reported that species sinica is well able to tolerate phenol and thiocyanate (J. Li et al., 2018a). The species asiatica is also found in phenol environment (Pereira et al., 2014).

\subsubsection{Other environment-specific species}

Species fulgida has the special characteristic of auto fluorescence. However, in some environments, the auto fluorescence will disappear (Böllmann et al., 2019). The shortest doubling time of anammox species was reported to be only $2.1 \mathrm{~d}$ by species sinica. Species sinica has a special $\mathrm{NH}_{2} \mathrm{OH}$ - dependent metabolic pathway (Oshiki et al., 2016). Under biodegradable organic matter (BOM) environment and high nitrate, species sinica still can grow (Shu et al., 2015; Li et al., 2016). Although some species belonging to Scalindua were discovered in WWTP, other species was seldom detected. The above characteristics of each species should be the basis for the exploration of proper anammox species for specific wastewater. In the quest to further the application of the annamox process, this should become a research spot.

\subsection{AOB species}

Five AOB genera have been detected belonging to the class Proteobacteria, as shown in Table 6. Four genera were classified to the $\beta$-Proteobacteria subclass, like Nitrosomonas, Nitrosospira, Nitrosovibrio and Nitrosolobus, while one genera, Nitrosococcus, belongs to the $\gamma$-Proteobacteria subclass. AOB characteristics and 
Table 6 The reported AOB species and their main features

\begin{tabular}{|c|c|c|c|c|c|}
\hline$\overline{\text { Class }}$ & Genus & Species & $\begin{array}{l}\text { Salt requirement } \\
(\%)\end{array}$ & $\begin{array}{l}\text { Max. Amm. affinity } \\
(\mathrm{mM})\end{array}$ & Preferred habitat \\
\hline \multirow[t]{18}{*}{$\begin{array}{l}\text { Beta } \\
\text { Proteobacteria }\end{array}$} & \multirow[t]{15}{*}{ Nitrosomonas } & Nitrosomonas europaea & 2.3 & 400 & $\begin{array}{c}\text { Common species in WWTPs; Sewage disposal } \\
\text { plants. }\end{array}$ \\
\hline & & Nitrosomonas eutropha & 2.3 & 600 & Sewage disposal plants/Eutrophic. \\
\hline & & Nitrosomonas halophila & 5.3 & 400 & Brackish water. \\
\hline & & Nitrosococcus mobilis & 2.9 & 250 & Eutrophic /Aquatic. \\
\hline & & Nitrosomonas communis & 1.5 & 250 & Moderate eutrophic $\mathrm{pH}$ neutral soils/Freshwater. \\
\hline & & Nitrosomonas nitrosa & 1.8 & 100 & $\begin{array}{c}\text { Eutrophic freshwater/Marine environment/ } \\
\text { WWTPs. }\end{array}$ \\
\hline & & Nitrosomonas oligotropha & 0.8 & 50 & Oligotrophic freshwater/Natural soils. \\
\hline & & Nitrosomonas ureae & 1.2 & 200 & Oligotrophic freshwater/Natural soils. \\
\hline & & Nitrosomonas marina & 4.8 & 200 & Marine. \\
\hline & & Nitrosomonas aestuarii & 3.6 & 400 & Marine. \\
\hline & & Nitrosomonas cryotolerans & 3.2 & 400 & Marine; Low temperature as low as $5^{\circ} \mathrm{C}$ ). \\
\hline & & Nitrosomonas sp. PY1 & n.d & n.d & Activated sludge. \\
\hline & & Nitrosomonas sp. NP1 & n.d & n.d & \\
\hline & & Nitrosomonas sp. SN1 & n.d & n.d & \\
\hline & & Nitrosomonas mobilis Ms 1 & n.d & n.d & WWTP granules. \\
\hline & Nitrosopira & Nitrosospira briensis & 1.5 & 200 & Natural soils/Freshwater/Marine. \\
\hline & Nitrosovibrio & Nitrosovibrio tenuis & 0.6 & 100 & Natural soils. \\
\hline & Nitrosolobus & Nitrosolobus multiformis & 1.2 & 50 & Soils/Sewage disposal plants. \\
\hline \multirow{4}{*}{$\begin{array}{l}\text { Gamma } \\
\text { Proteobacteria }\end{array}$} & \multirow[t]{3}{*}{ Nitrosococcus } & Nitrosococcus oceani & 6.4 & 1000 & Marine. \\
\hline & & Nitrosococcus halophilus & 10.5 & 500 & Marine/Salt lakes. \\
\hline & & $\begin{array}{l}\text { Nitrosococcus wardiae } \\
\text { DIFHS }\end{array}$ & n.d & n.d & Eutrophic marine sediment. \\
\hline & Nitrosoglobus & Nitrosoglobus terrae & n.d & n.d & Acidic soil. \\
\hline
\end{tabular}

predominant species vary based on the treatment configuration, substrate and experimental conditions (Aoi et al., 2000).

\subsubsection{Carbon source-specific species}

The common species in WWTPs $N$. is europaea. The AOB which has been characterized in the most detail is the bacterium $N$. europaea so far (Woebken et al., 2020). In biofilm reactor, there is an interesting phenomenon between $N$. europaea and associated heterotrophic bacteria: with a limited BOM environment, through ammonium oxidation, the $N$. europaea provide BOM to heterotrophic bacteria, which then forms a biofilm suitable for the attachment of $N$. europaea (Keshvardoust et al., 2019).

\subsubsection{Salinity-specific species}

In the treatment of sidestream wastewater, salinity increases from zero to $3.0 \%$, and $N$. europaea and
Nitrosomoccus mobilis are the salinity-tolerated AOB species. Especially, Nitrosomoccus has been shown to the extremely high salinity-tolerant (Guo et al., 2020c).

In the case of mainstream wastewater with low salinity, $N$. marina was dominant, while with high salinity, $N$. oligotropha was dominant (Wu et al., 2020). In a WWTP, with a high salinity level, $N$. marina were found dominant, while with low salinity level, $N$. urea became dominant (Wu et al., 2013). In treating wastewater from a thermal power plant, it was reported that $N$. halophila was responsible for ammonium oxidation.

\subsubsection{Temperature-specific species}

AOB benefits more from high temperatures than NOB. However, in actual application, a high-energy input is a concern for the high temperature environment. With a high temperature of $35^{\circ} \mathrm{C}-45^{\circ} \mathrm{C}$ and industrial wastewater treatment, $N$. nitrosa was observed (Shore et al., 2012). It was reported that $N$. communis could adapted to the high temperature in soil (Bei et al., 2021). In a sequence batch 
reactor (SBR), with the temperature decreased from $25^{\circ} \mathrm{C}$ to $12^{\circ} \mathrm{C}$ and the control of FA, N. eutropha and N. nitrosa were found to be more fierce than other species (Qi et al., 2020).

\subsubsection{Dissolved oxygen (DO)-specific species}

The AOB has a higher affinity for oxygen than NOB. The growth yield of AOB was twice that of NOB under a limited DO environment (Guo et al., 2020c). It was found that in a high DO environment, $N$. oligotropha was dominant, while in a low DO environment, $N$. europaea were enriched (Liu et al., 2019).

\subsubsection{Substrate concentration-specific species}

AOB can also be divided into the k-strategists and rstrategists (Soliman and Eldyasti, 2018). Based on a study from 11 WWTPs, the dominant species were $N$. europaea and $N$. eutropha under high ammonium environment, whereas $N$. ureae, $N$. oligotropha and $N$. marina were dominant under the low ammonium environment (Otawa et al., 2006). At a low NLR, the predominant AOB species was $N$. europaea, while at a high NLR, it was $N$. oligotropha (Zhang et al., 2018). For steel wastewater treatment with a high ammonium content, $N$. aestuarii $\mathrm{s}$ survived for nitritation (Cho et al., 2016). In various WWTPs, $N$. mobilis is an important AOB. $N$. mobilis was shown to be able to tolerate nitrite at $300 \mathrm{mM}$ (Thandar et al., 2016).

FA and FNA can inhibit AOB and NOB (Zhang et al., 2021). A proper high FA concentration favors AOB growth over NOB growth. However, it was reported that FA inhibition for NOB is reversible. It was reported that the most effective inhibition strategy for NOB was the control of FA and FNA at a temperature below $25^{\circ} \mathrm{C}$.

\subsection{Denitratation species}

Group A and group B are the two groups of DB with BOM, (Martienssen, 1997; Phanwilai et al., 2020), as shown in Table 7. Group A can only convert nitrate to nitrite, while group B can first convert nitrate to nitrite, then after the depletion of nitrate, it further converts the accumulated nitrite to nitrogen gas. In practice, these two groups of denitratation bacteria coexist in WWTPs. BOM can also be used for denitrification, which is conducted by denitrifying glycogen-accumulating organisms (DGAOs), as shown in Table 7.

The microbe community, organic matter and $\mathrm{pH}$ may affect nitrate reduction by DB. It has been reported that high $\mathrm{pH}$ conditions were beneficial to achieve denitratation with a denitrification reactor (Si et al., 2018). The extent of the effects is also depend on the duration time (Ma et al., 2020b). Some drawbacks facing the practical application of denitratation. First, the growth rate of the anammox biomass would be significantly suppressed by DB. The higher biomass yield and growth rate of DB could prevent substrate transfer for anammox bacteria, finally reducing the NRE (Lotti et al., 2015; Zhang et al., 2017). Thus, it is crucial to control the BOM content in influent. Second, some kinds of anammox bacteria can alter their metabolism pathway with the existence of other electron donors, like propionate.

\subsection{DAMO species}

The microbes involved in the DAMO reaction are shown in Table 8. DAMO and anammox have some similarities: both are characterized by the slow grow rate of microbes and show potential for actual application. In the DAMO reaction, DAMO-archaea reduced nitrate to nitrite coupled to methane oxidation, while DAMO-bacteria reduce the generated nitrite to nitrogen gas (Fu et al., 2017a).

Table 7 The reported denitratation species and their main features

\begin{tabular}{|c|c|c|c|}
\hline Carbon source type & Categories & Species & Characteristics \\
\hline \multirow{6}{*}{$\begin{array}{l}\text { Exogenous carbon } \\
\text { source }\end{array}$} & \multirow[t]{2}{*}{ Group A } & Staphylococcus sp. & Only capable of reducing nitrate to nitrite. \\
\hline & & Rhodobacter sphaeroides 2.4 .1 & Contains nitrate reductase but not nitrite reductase. \\
\hline & \multirow[t]{4}{*}{ Group B } & Thauera aminoaromaticaa & Showing a progressive onset $(\mathrm{PO})$ of denitrification genes, with no transcription \\
\hline & & Thauera phenylaceticaa & $\begin{array}{l}\text { of nirS (encoding nitrite reductase) detected until all nitrate was reduced, } \\
\text { resulting in the accumulation of nitrite. }\end{array}$ \\
\hline & & Thauera sp. DNT-1 & \\
\hline & & Thauera terpenicaa & \\
\hline \multirow{6}{*}{$\begin{array}{l}\text { Endogenous carbon } \\
\text { sources }\end{array}$} & \multirow[t]{6}{*}{ DGAOs } & Dechloromonas & Very rapid in assimilation of propionate. \\
\hline & & Accumulibacter & Could behave as GAO under poly-P-limiting conditions. \\
\hline & & Comamonadaceae unclassified & Could transform carbon sources into PHAs for denitritation. \\
\hline & & Thermomonas & Mainly utilize nitrate under acetate conditions. \\
\hline & & Dechloromonas & $\begin{array}{c}\text { Played a key role in carbon glycolysis and acidification of slowly biodegradable } \\
\text { organic matter. }\end{array}$ \\
\hline & & Saccharibacteria & Enriched in glycerol-driven reactors. \\
\hline
\end{tabular}


Table 8 The reported DAMO species and their main features

\begin{tabular}{|c|c|c|}
\hline Microbe & Species & Characteristics \\
\hline \multirow[t]{4}{*}{$\begin{array}{l}\text { DAMO } \\
\text { bacteria }\end{array}$} & M. oxyfera & $\begin{array}{c}\text { Rod-shaped; } 0.25-0.5 \times 0.8-1.1 \mu \mathrm{m} ; \text { A slow doubling time of } 11.5 \mathrm{~d} \text { was estimated; Dominated in highly contaminated } \\
\text { nitrate and oxygen environment; Harbors three methanol dehydrogenases. }\end{array}$ \\
\hline & M. sinica & Enriched in the nitrite reactor; roughly coccus-shaped $(0.7-1.2 \mu \mathrm{m})$; Grew in honeycomb-shaped microcolonies; \\
\hline & M. limnetica & $\begin{array}{l}\text { Dominated the planktonic microbial community in the anoxic depths of the deep stratified Lake; } \\
\text { Constituted up to one third of all metatranscriptomic sequences in situ; The reconstructed genome encoded a complete } \\
\text { pathway for methane oxidation, and an incomplete denitrification pathway, including two putative nitric oxide dismutase } \\
\text { genes. }\end{array}$ \\
\hline & M. lanthanidiphyla & $\begin{array}{c}\text { Enrichment of 'Ca. M. oxyfera' with cerium added as trace element and without nitrate; Encode a lanthanide-dependent } \\
\text { XoxF-type methanol dehydrogenases. }\end{array}$ \\
\hline $\begin{array}{l}\text { DAMO } \\
\text { archaea }\end{array}$ & $\begin{array}{c}\text { Methanoperedens } \\
\text { nitroreducens }\end{array}$ & $\begin{array}{l}\text { Comply with first order kinetic model with a rate constant of } 0.019 \pm 0.006 \mathrm{~h}^{-1} \text { and a biomass-specific rate constant of } \\
0.04-0.14 \mathrm{~L} /(\mathrm{h} \times \mathrm{g}-\mathrm{VSS}) \text {; Capable of independent AOM through reverse methanogenesis using nitrate as the terminal } \\
\text { electron acceptor. }\end{array}$ \\
\hline
\end{tabular}

M. oxyfera is classified as a "NC10" phylum (Fu et al., 2017b). This bacterial species has a unique ultrastructure that is distinct from that of other previously described microorganisms. $M$. oxyfera reduces nitrite to nitric oxide and then achieves methane oxidation using the in situ produced oxygen from the dismutation of nitric oxide. $M$. nitroreducens reduces nitrate to nitrite with methane served as the electron supplier. In contrast to M. oxyfera, which employs aerobic methane oxidation, M. nitroreducens oxidizes methane through reverse methanogenesis. This pathway was very recently proven. $M$. nitroreducens has a slightly higher affinity constant for nitrate than that of most known denitrifying bacteria ( $\mathrm{Lu}$ et al., 2019). It was reported that the optimized temperature for DAMOarchaea reaction is $35^{\circ} \mathrm{C}$. At both $\mathrm{pH} 6.5$ and 7.5 , the maximum DAMO-archaea reaction rate appeared. It was reported that the DAMO-archaea is inhibited in environments with the existence of DO (Lou et al., 2020). It was also reported that in MBfR, DAMO-archaea could convert nitrate to ammonium (Nie et al., 2021).

The low activity and slow doubling times of DAMO microbes have limited its practical application. However, the strategy of adding Geobacter sulfurreducens and hydroxyapatite was shown to stimulate the DAMO process due to the acceleration of electron transfer through conductive materials (Chang et al., 2021a, 2021b). It was also reported that the DAMO activity was obviously stimulated by the nucleobase and betaine (Wang et al., 2019). Supplementation of basal medium with $P Q Q$ is also an effective strategy for the enrichment DAMO-bacteria (Hatamoto et al., 2018).

The enrichment of DAMO culture can be conducted with the SBR reactor configuration (W. Li et al., 2018). The successful cultivation of DAMO-bacteria granules was conducted with the SBR reactor (He et al., 2015a). It was reported that DAMO-archaea could be enriched by regulating the trace element iron (Lu et al., 2018), and that the cultivation of the DAMO-bacteria by the magnetically stirred gas lift reactor is also desirable.
Freshwater canal sediment, freshwater lake sediment, paddy soil, anaerobic digester sludge and return activated sludge from a sewage treatment plant have been successfully adopted as inoculum for DAMO cultivation (Shen et al., 2015). The metabolic activity and growth rate of DAMO-bacteria were affected by temperature, $\mathrm{pH}$ and salinity (He et al., 2015b).

It was reported that under an environment with both nitrite and ammonium, the competency of DAMO-bacteria is lower than anammox bacteria (Hu et al., 2015; Stultiens et al., 2019). However, in the one-stage PN-DAMO/A process in an MBfR, the $\mathrm{AOB}$, anammox bacteria, DAMO-bacteria and DAMO-archaea coexisted in the biofilm (T. Liu et al., 2019). DAMO-bacteria has high diversity in the nitrate reactor, with one similar to $M$. oxyfera, while the DAMO-bacteria in the nitrite reactor were relatively unified and close to $M$. sinica (Fu et al., 2017b). In a high nitrate and oxygen environment, Methylomirabilis was the dominant population (Luo et al., 2018). It was also proposed that adopting the lowtemperature operation to enhance methane dissolution, which also can reduce the cost of warming the reactor $(\mathrm{Li}$ et al., 2020).

With salinity as high as $84 \mathrm{~g} / \mathrm{L}$, it was also found that DAMO and anammox bacteria could co-occur (Yang et al., 2012). The optimum salinity for the metabolic activity and growth rate of DAMO-bacteria is $0 \mathrm{~g} \mathrm{NaCl} / \mathrm{L}$. Under salinity stress of $20 \mathrm{~g} \mathrm{NaCl} /$, salinity adaption of DAMObacteria was also found (He et al., 2015b).

\section{The existing outstanding problems}

From above, it is obvious that while there has been clear progress in the anammox-based processes, there are still questions which need to be resolved from the actual application perspective and a more comprehensive perspective. 


\subsection{The competence relationship between PD and DAMO}

It is known that in some kinds of wastewater, like digestion effluent, there is both BOM and dissolved methane in the liquid (Liu et al., 2021). For the utilization of this dissolved methane as an electron donor in the DAMO process, the DAMO process for nitrate reduction should come before the PD process since the methane easily escapes from the liquid. However, there are no reports about the effect of $\mathrm{BOM}$ on the DAMO process. Even in the DAMO reactor, with the synchronic existence of BOM, it remains unclear whether the DB forms the competition relationship with the DAMO-archaea for nitrate. These points should be considered in future research focused on utilizing the dissolved methane in the digestion effluent.

\subsection{The release of methane from the influent}

Methane is one of the least reactive organic molecules. In the treatment of digestion effluent, because the discharged effluent is exposed to the open air, it is crucial to find a way to effectively capture the methane for DAMO reaction and not allow it to be simply released to the air. With the escape of methane from liquid, not only is the DAMO activity effected, but the released methane is an environmental problem (Shi et al., 2013). This highlight the importance and complexity of operating the DAMO reactor well.

\subsection{The precise control of methane and BOM supply}

In actual applications, the precise control of methane and BOM in the influent from the anaerobic reactor is an important point for the healthy conversion of nitrate. The excessive supply of methane not only causes the loss of methane production in the upstream anaerobic fermenta- tion step, but also results in greenhouse gas emissions (Guo et al., 2020a). The inadequate supply of methane and BOM in the influent results in a slowdown in the microbe metabolism. Thus, cooperation between the upstream and the downstream is necessary to balance the energy recovery and the carbon source utilization.

\section{The proposed novel process system for waste treatment}

Considering all the above, it is possible to propose a novel integrated system for waste treatment based on an overall perspective. This system is comprised of two process lines with the exchange of substances in order to maximize the utilization of existing substances, like nitrogen species, methane, and organic matter in wastewater. A schematic of this system is shown in Fig. 5. In the mainstream wastewater treatment process line, the organic matter in mainstream wastewater is first removed through the COD capture process, making the effluent suitable for nitrogen removal through PN/A process (Guo et al., 2020b). The settled sludge is transferred to the anaerobic fermentation reactor for methane gas production. Due to the imbalance of nutrient substances in the sludge, other biomass waste (like waste from the food industry, stockbreeding, and agriculture) can also be poured into the anaerobic reactor to enhance methane production. The discharge of the anaerobic fermentation reactor can be divided into two kinds: the solid fermentation dregs, which can be utilized as fertilizer, and the digestion liquid with a high ammonium concentration, phosphorus, and organic matter and dissolved methane, which can be transferred to the sidestream wastewater treatment line (Guo and Li, 2020). The digestion liquid is first transferred to the DAMO/

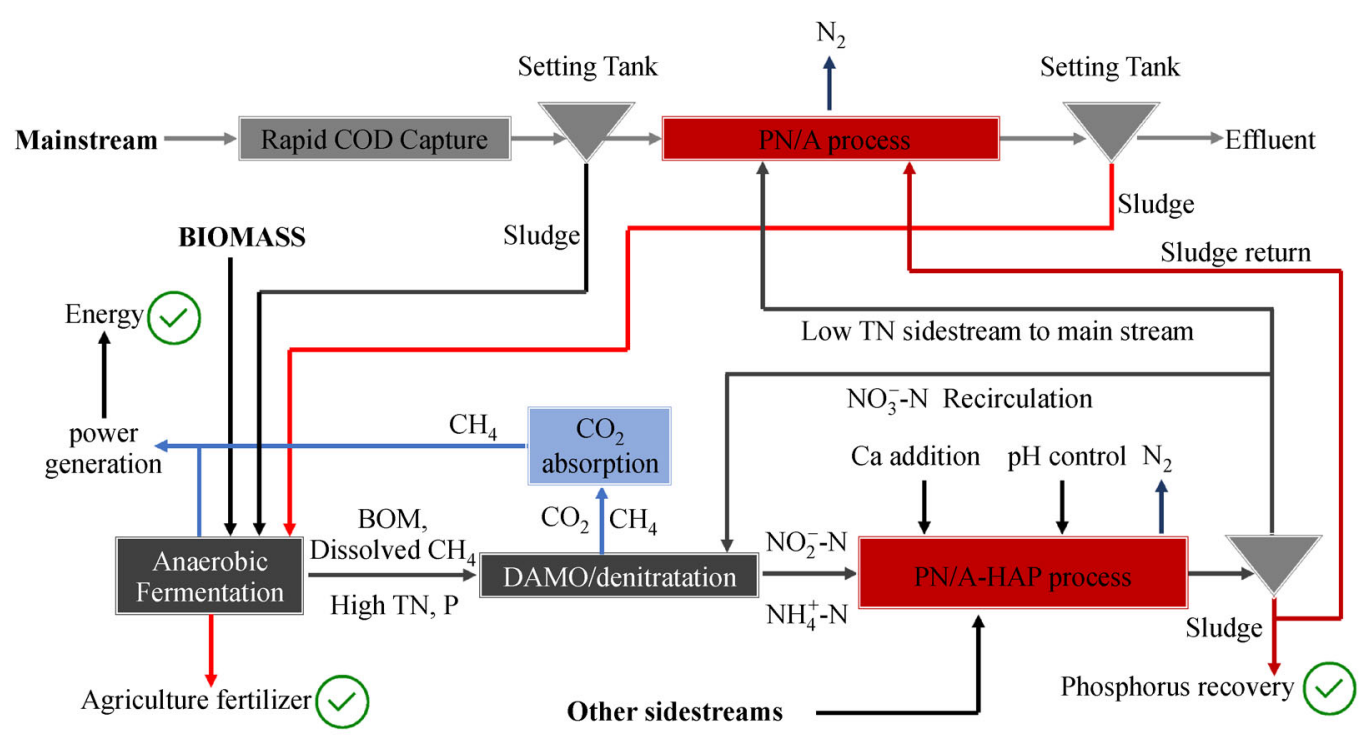

Fig. 5 The proposed future waste treatment system integrating each anammox-based processes. 
denitratation reactor for methane and organic matter utilization for the removal of nitrate, which comes from the later PN/A-HAP reactor. In the DAMO/denitratation reactor, with the production of $\mathrm{CO}_{2}$, the partial pressure of methane is further reduced according to the henry law, resulting in the escape of methane from the fermentation liquid, and the gas contain the methane and the carbon dioxide. This gas is passed through the carbon dioxide absorption equipment to recover the high quality methane gas, ensuring no detrimental greenhouse effect from the process. After removing the methane and organic matter, the digestion liquid enters the PN/A-HAP reactor for nitrogen removal and phosphorus recovery (Guo and Li, 2020). Of course, other types of sidestream wastewater (like fill land leachate, fertilizer industry, electron industry) are also well-suited to the PN/A-HAP reactor. The nitrate in the effluent produced by the anammox reaction can be partly recirculated to the DAMO/denitratation reactor for nitrite production (Du et al., 2015), which can then be sent to the PN/A-HAP reactor for removal. The formed sludge, which has a good settling property, can be transformed to the PN/A reactor for mainstream wastewater treatment (Guo et al., 2021). It is acknowledged that achieving the removal of all of the nitrogen in the PN/A-HAP reactor is not possible due to the high cost and the need for precise control. However, with the most of nitrogen species in the digestion effluent being removed, the low total nitrogen effluent can be transformed to the mainstream wastewater treatment process line for further nitrogen removal. In the PN/A reactor, both the mainstream wastewater and the effluent of PN/A-HAP reactor can be merged for further nitrogen removal. The effluent of the HAP reactor after settling can be discharged, while the settled sludge can be transformed to the fermentation reactor for methane production again. The only sludge discharge location is on the PN/A-HAP reactor. Due to the high phosphorus content in the sludge, the potential for phosphorus recovery from the sludge is promising (Guo and $\mathrm{Li}, 2020$ ).

The future waste treatment system is not just focusing on the wastewater. The application scenario of this future waste treatment system is the mainstream, sidestream, and the organic waste, like the food waste, kitchen waste, activated sludge and so on, discharged by the whole society. It targets at the carbon, nitrogen and the phosphorus in the wastewater and the organic wastewater. Through the combination of a lot of novel processes, the most effective treatment can be achieved from many perspectives, like the energy recovery, the low-cost nitrogen removal, the phosphorus resource recovery, and the minimum environment effect.

\section{Conclusions}

In recent years, there have been significant developments in the anammox-based process toward its wide practical application. Many novel anammox-based processes have been developed by combining the anammox process with other processes, like denitratation and the DAMO process. Among them, the PN/A process, the DN/A process and the $\mathrm{DAMO} / \mathrm{A}$ process have received considerable attention due to their practical operability in actual wastewater treatment. Novel technologies like the PN/A-HAP process and the CN-PN/A process have paved the way to mainstream wastewater treatment. While the nitrogen removal performance of the DAMO/A process has been demonstrated to be both excellent and thorough, further exploration considering reducing the cost and the complexity is required for actual application. Since there is considerable diversity in the metabolic activity of the functional microbes in the anammox-based process, further exploration to optimize the specific characteristics in actual applications is promising. Through the effective allocation of each anammox-based processes in the whole waste treatment system, it is considered feasible to maximize energy and resource recovery and minimization the detrimental effect on the environment in waste treatment.

Acknowledgements This work was financially supported by Japan Society for the Promotion of Science (JSPS) (No. 19H01160) and the China Scholarship Council (No. 201606460046).

Open Access This article is licensed under a Creative Commons Attribution 4.0 International License, which permits use, sharing, adaptation, distribution and reproduction in any medium or format, as long as you give appropriate credit to the original author(s) and the source, provide a link to the Creative Commons licence, and indicate if changes were made. The images or other third party material in this article are included in the article's Creative Commons licence, unless indicated otherwise in a credit line to the material. If material is not included in the article's Creative Commons licence and your intended use is not permitted by statutory regulation or exceeds the permitted use, you will need to obtain permission directly from the copyright holder. To view a copy of this licence, visit http://creativecommons.org/licenses/by/4.0/.

\section{References}

Antwi P, Zhang D, Su H, Luo W, Quashie F K, Kabutey F T, Xiao L, Lai C, Liu Z, Li J (2020). Nitrogen removal from landfill leachate by single-stage anammox and partial-nitritation process: Effects of microaerobic condition on performance and microbial activities. Journal of Water Process Engineering, 38: 101572

Aoi Y, Miyoshi T, Okamoto T, Tsuneda S, Hirata A, Kitayama A, Nagamune $T$ (2000). Microbial ecology of nitrifying bacteria in wastewater treatment process examined by fluorescence in situ hybridization. Journal of Bioscience and Bioengineering, 90(3): 234240

Bei S, Tian Y, Zhao J, Zhang H, Christie P, Li X, Jia Z, Zhang J (2021). Temperature-dependent changes in active nitrifying communities in response to field fertilization legacy. Biology and Fertility of Soils, 57 (1): $1-14$

Bi Z, Wanyan D, Li X, Huang Y (2020). Biological conversion pathways of sulfate reduction ammonium oxidation in anammox consortia. 
Frontiers of Environmental Science \& Engineering, 14(3): 38-11

Böllmann J, Engelbrecht S, Martienssen M (2019). Autofluorescent characteristics of Candidatus Brocadia fulgida and the consequences for FISH and microscopic detection. Systematic and Applied Microbiology, 42(2): 135-144

Cai C, Hu S, Guo J, Shi Y, Xie G J, Yuan Z (2015). Nitrate reduction by denitrifying anaerobic methane oxidizing microorganisms can reach a practically useful rate. Water Research, 87: 211-217

Cao Y, van Loosdrecht M C M, Daigger G T (2017). Mainstream partial nitritation-anammox in municipal wastewater treatment: status, bottlenecks, and further studies. Applied Microbiology and Biotechnology, 101(4): 1365-1383

Castro-Barros C M, Jia M, van Loosdrecht M C M, Volcke E I P, Winkler M K H (2017). Evaluating the potential for dissimilatory nitrate reduction by anammox bacteria for municipal wastewater treatment. Bioresource Technology, 233: 363-372

Chen H, Tu Z, Wu S, Yu G, Du C, Wang H, Yang E, Zhou L, Deng B, Wang D, Li H (2021). Recent advances in partial denitrificationanaerobic ammonium oxidation process for mainstream municipal wastewater treatment. Chemosphere 278, 130436. https://doi.org/ $10.1016 / \mathrm{j}$.

Chang J, Wu Q, Liang P, Huang X (2021a). Enhancement of nitritedependent anaerobic methane oxidation via Geobacter sulfurreducens. Science of the Total Environment, 766: 144230

Chang J, Wu Q, Yan X, Wang H, Lee L W, Liu Y, Liang P, Qiu Y, Huang X (2021b). Enhancement of nitrite reduction and enrichment of Methylomonas via conductive materials in a nitrite-dependent anaerobic methane oxidation system. Environmental Research, 193: 110565

Chen R, Ji J, Chen Y, Takemura Y, Liu Y, Kubota K, Ma H, Li Y Y (2019). Successful operation performance and syntrophic microgranule in partial nitritation and anammox reactor treating lowstrength ammonia wastewater. Water Research, 155: 288-299

Cho K, Choi M, Lee S, Bae H (2018). Negligible seeding source effect on the final ANAMMOX community under steady and high nitrogen loading rate after enrichment using poly(vinyl alcohol) gel carriers. Chemosphere, 208: 21-30

Cho K, Shin S G, Lee J, Koo T, Kim W, Hwang S (2016). Nitrification resilience and community dynamics of ammonia-oxidizing bacteria with respect to ammonia loading shock in a nitrification reactor treating steel wastewater. Journal of Bioscience and Bioengineering, 122(2): 196-202

Deng Y F, Ekama G A, Cui Y X, Tang C J, van Loosdrecht M C M, Chen G H, Wu D (2019). Coupling of sulfur(thiosulfate)-driven denitratation and anammox process to treat nitrate and ammonium contained wastewater. Water Research, 163: 114854

Ding J, Seow W, Zhou J, Zeng R J, Gu J, Zhou Y (2021). Effects of Fe (II) on anammox community activity and physiologic response. Frontiers of Environmental Science \& Engineering, 15(1): 7

Ding Z W, Lu Y Z, Fu L, Ding J, Zeng R J (2017). Simultaneous enrichment of denitrifying anaerobic methane-oxidizing microorganisms and anammox bacteria in a hollow-fiber membrane biofilm reactor. Applied Microbiology and Biotechnology, 101(1): 437-446

Du R, Peng Y, Cao S, Wang S, Wu C (2015). Advanced nitrogen removal from wastewater by combining anammox with partial denitrification. Bioresource Technology, 179: 497-504
Du R, Peng Y, Ji J, Shi L, Gao R, Li X (2019). Partial denitrification providing nitrite: Opportunities of extending application for anammox. Environment International, 131: 105001

Fan S Q, Xie G J, Lu Y, Liu B F, Xing D F, Han H J, Yuan Z, Ren N Q (2020). Granular sludge coupling nitrate/nitrite dependent anaerobic methane oxidation with anammox: From proof-of-concept to high rate nitrogen removal. Environmental Science \& Technology, acs. est.9b02528

Fang K, Peng F, Gong H, Zhang H, Wang K (2021). Ammonia removal from low-strength municipal wastewater by powdered resin combined with simultaneous recovery as struvite. Frontiers of Environmental Science \& Engineering, 15(8): 1-10

Fu J, Zhang Q, Huang B, Fan N, Jin R (2021). A review on anammox process for the treatment of antibiotic-containing wastewater: Linking effects with corresponding mechanisms. Frontiers of Environmental Science \& Engineering, 15(1): 17

Fu L, Ding J, Lu Y Z, Ding Z W, Bai Y N, Zeng R J (2017a). Hollow fiber membrane bioreactor affects microbial community and morphology of the DAMO and Anammox co-culture system. Bioresource Technology, 232: 247-253

Fu L, Ding J, Lu Y Z, Ding Z W, Zeng R J (2017b). Nitrogen source effects on the denitrifying anaerobic methane oxidation culture and anaerobic ammonium oxidation bacteria enrichment process. Applied Microbiology and Biotechnology, 101(9): 3895-3906

Gonzalez-Silva B M, Rønning A J, Andreassen I K, Bakke I, Cervantes F J, Østgaard K, Vadstein O (2017). Changes in the microbial community of an anammox consortium during adaptation to marine conditions revealed by 454 pyrosequencing. Applied Microbiology and Biotechnology, 101(12): 5149-5162

Guo Y, Chen Y, Webeck E, Li Y Y (2020a). Towards more efficient nitrogen removal and phosphorus recovery from digestion effluent: Latest developments in the anammox-based process from the application perspective. Bioresource Technology, 299: 122560

Guo Y, Li Y Y (2020). Hydroxyapatite crystallization-based phosphorus recovery coupling with the nitrogen removal through partial nitritation/anammox in a single reactor. Water Research, 187: 116444

Guo Y, Niu Q, Sugano T, Li Y Y (2020b). Biodegradable organic matter-containing ammonium wastewater treatment through simultaneous partial nitritation, anammox, denitrification and COD oxidization process. Science of the Total Environment, 714: 136740

Guo Y, Sugano T, Song Y, Xie C, Chen Y, Xue Y, Li Y Y (2020c). The performance of freshwater one-stage partial nitritation/anammox process with the increase of salinity up to 3.0. Bioresource Technology, 311: 123489

Guo Y, Xie C, Chen Y, Urasaki K, Qin Y, Kubota K, Li Y Y (2021). Achieving superior nitrogen removal performance in low-strength ammonium wastewater treatment by cultivating concentrated, highly dispersive, and easily settleable granule sludge in a one-stage partial nitritation/anammox-HAP reactor. Water Research, 200: 117217

Hatamoto M, Nemoto S, Yamaguchi T (2018). Effects of copper and PQQ on the denitrification activities of microorganisms facilitating nitrite- and nitrate-dependent DAMO reaction. International Journal of Environmental Research, 12(5): 749-753

He Z, Geng S, Pan Y, Cai C, Wang J, Wang L, Liu S, Zheng P, Xu X, Hu B (2015a). Improvement of the trace metal composition of medium for nitrite-dependent anaerobic methane oxidation bacteria: Iron(II) 
and copper(II) make a difference. Water Research, 85: 235-243

He Z, Geng S, Shen L, Lou L, Zheng P, Xu X, Hu B (2015b). The shortand long-term effects of environmental conditions on anaerobic methane oxidation coupled to nitrite reduction. Water Research, 68: $554-562$

Hu S, Zeng R J, Haroon M F, Keller J, Lant P A, Tyson G W, Yuan Z (2015). A laboratory investigation of interactions between denitrifying anaerobic methane oxidation (DAMO) and anammox processes in anoxic environments. Scientific Reports, 5(1): 8706

Kartal B, Kuypers M M M, Lavik G, Schalk J, Op den Camp H J M, Jetten M S M, Strous M (2007a). Anammox bacteria disguised as denitrifiers: Nitrate reduction to dinitrogen gas via nitrite and ammonium. Environmental Microbiology, 9(3): 635-642

Kartal B, Rattray J, van Niftrik L A, van de Vossenberg J, Schmid M C, Webb R I, Schouten S, Fuerst J A, Damsté J S, Jetten M S M, Strous M (2007b). Candidatus "Anammoxoglobus propionicus" a new propionate oxidizing species of anaerobic ammonium oxidizing bacteria. Systematic and Applied Microbiology, 30(1): 39-49

Keshvardoust P, Huron V A A, Clemson M, Constancias F, Barraud N, Rice S A(2019). Biofilm formation inhibition and dispersal of multispecies communities containing ammonia-oxidising bacteria. npj Biofilms Microbiomes 5, 25-28

Li J, Bai L, Qiang Z, Dong H, Wang D (2018). Nitrogen removal through "Candidatus Brocadia sinica" treating high-salinity and lowtemperature wastewater with glycine addition: Enhanced performance and kinetics. Bioresource Technology, 270: 755-761

Li J, Qiang Z, Yu D, Wang D, Zhang P, Li Y (2016). Performance and microbial community of simultaneous anammox and denitrification (SAD) process in a sequencing batch reactor. Bioresource Technology, 218: 1064-1072

Li S, Zhou X, Cao X, Chen J (2021). Insights into simultaneous anammox and denitrification system with short-term pyridine exposure: Process capability, inhibition kinetics and metabolic pathways. Frontiers of Environmental Science \& Engineering, 15 (6): 139

Li W, Cai Z Y, Duo Z J, Lu Y F, Gao K X, Abbas G, Zhang M, Zheng P (2017). Heterotrophic ammonia and nitrate bio-removal over nitrite (Hanbon): Performance and microflora. Chemosphere, 182: $532-538$

Li W, Lu P, Chai F, Zhang L, Han X, Zhang D (2018). Long-term nitrate removal through methane-dependent denitrification microorganisms in sequencing batch reactors fed with only nitrate and methane. AMB Express, 8(1): 108

Li W, Lu P, Zhang L, Ding A, Wang X, Yang H, Zhang D (2020). Longterm performance of denitrifying anaerobic methane oxidation under stepwise cooling and ambient temperature conditions. Science of the Total Environment, 713: 136739

Li X, Sun S, Yuan H, Badgley B D, He Z (2017). Mainstream upflow nitritation-anammox system with hybrid anaerobic pretreatment: Long-term performance and microbial community dynamics. Water Research, 125: 298-308

Li Y, Li J, Zhao B, Wang X, Zhang Y, Wei J, Bian W (2017). A coupled system of half-nitritation and ANAMMOX for mature landfill leachate nitrogen removal. Environmental Technology, 38(18): 2335-2343

Liu C, Liu T, Zheng X, Meng J, Chen H, Yuan Z, Hu S, Guo J (2021).
Rapid formation of granules coupling n-DAMO and anammox microorganisms to remove nitrogen. Water Research, 194: 116963

Liu T, Hu S, Yuan Z, Guo J (2019). High-level nitrogen removal by simultaneous partial nitritation, anammox and nitrite/nitrate-dependent anaerobic methane oxidation. Water Research, 166: 115057

Liu T, Khai Lim Z, Chen H, Hu S, Yuan Z, Guo J (2020). TemperatureTolerated Mainstream Nitrogen Removal by Anammox and Nitrite/ Nitrate-Dependent Anaerobic Methane Oxidation in a Membrane Biofilm Reactor. Environmental Science \& Technology, 54(5): 30123021

Liu W, Chen W, Yang D, Shen Y (2019). Functional and compositional characteristics of nitrifiers reveal the failure of achieving mainstream nitritation under limited oxygen or ammonia conditions. Bioresource Technology, 275: 272-279

Lotti T, Kleerebezem R, van Loosdrecht M C M (2015). Effect of temperature change on anammox activity. Biotechnology and Bioengineering, 112(1): 98-103

Lou J, Lv J, Yang D (2020). Effects of Environmental Factors on NitrateDAMO Activity. Water, Air, and Soil Pollution, 231(6): 263

Lu P, Liu T, Ni B J, Guo J, Yuan Z, Hu S (2019). Growth kinetics of Candidatus 'Methanoperedens nitroreducens' enriched in a laboratory reactor. Science of the Total Environment, 659: 442-450

Lu Y Z, Fu L, Li N, Ding J, Bai Y N, Samaras P, Zeng R J (2018). The content of trace element iron is a key factor for competition between anaerobic ammonium oxidation and methane-dependent denitrification processes. Chemosphere, 198: 370-376

Luo J H, Chen H, Yuan Z, Guo J (2018). Methane-supported nitrate removal from groundwater in a membrane biofilm reactor. Water Research, 132: 71-78

Ma B, Qian W, Yuan C, Yuan Z, Peng Y (2017). Achieving Mainstream Nitrogen Removal through Coupling Anammox with Denitratation. Environmental Science \& Technology, 51(15): 8405-8413

Ma B, Xu X, Ge S, Li B, Wei Y, Zhu H, Nan X, Peng Y (2020a). Reducing carbon source consumption through a novel denitratation/ anammox biofilter to remove nitrate from synthetic secondary effluent. Bioresource Technology, 309: 123377

Ma B, Xu X, Wei Y, Ge C, Peng Y (2020b). Recent advances in controlling denitritation for achieving denitratation/anammox in mainstream wastewater treatment plants. Bioresource Technology, 299: 122697

Martienssen M (1997). Biological treatment of leachate from solid waste landfill sites: Alterations in the bacterial community during the denitrification process. Water Research, 31(5): 1164-1170

Nejidat A, Diaz-Reck D, Massalha N, Arbiv A, Dawas A, Dosoretz C, Sabbah I (2018). Abundance and diversity of anammox bacteria in a mainstream municipal wastewater treatment plant. Applied Microbiology and Biotechnology, 102(15): 6713-6723

Nie W B, Ding J, Xie G J, Yang L, Peng L, Tan X, Liu B F, Xing D F, Yuan Z, Ren N Q (2021). Anaerobic oxidation of methane coupled with dissimilatory nitrate reduction to ammonium fuels anaerobic ammonium oxidation. Environmental Science \& Technology, 55(2): $1197-1208$

Nie W B, Xie G J, Ding J, Lu Y, Liu B F, Xing D F, Wang Q, Han H J, Yuan Z, Ren N Q (2019). High performance nitrogen removal through integrating denitrifying anaerobic methane oxidation and Anammox: from enrichment to application. Environment Interna- 
tional, 132: 105107

Oshiki M, Ali M, Shinyako-Hata K, Satoh H, Okabe S (2016). Hydroxylamine-dependent anaerobic ammonium oxidation (anammox) by "Candidatus Brocadia Sinica". Environmental Microbiology, 18(9): 3133-3143

Oshiki M, Masuda Y, Yamaguchi T, Araki N (2018). Synergistic inhibition of anaerobic ammonium oxidation (anammox) activity by phenol and thiocyanate. Chemosphere, 213: 498-506

Otawa K, Asano R, Ohba Y, Sasaki T, Kawamura E, Koyama F, Nakamura S, Nakai Y (2006). Molecular analysis of ammoniaoxidizing bacteria community in intermittent aeration sequencing batch reactors used for animal wastewater treatment. Environmental Microbiology, 8(11): 1985-1996

Park H, Sundar S, Ma Y, Chandran K (2015). Differentiation in the microbial ecology and activity of suspended and attached bacteria in a nitritation-anammox process. Biotechnology and Bioengineering, 112(2): 272-279

Pereira A D, Leal C D, Dias M F, Etchebehere C, Chernicharo C A L, de Araújo J C (2014). Effect of phenol on the nitrogen removal performance and microbial community structure and composition of an anammox reactor. Bioresource Technology, 166: 103-111

Phanwilai S, Kangwannarakul N, Noophan P (2020). Nitrogen removal efficiencies and microbial communities in full-scale IFAS and MBBR municipal wastewater treatment plants at high COD:N ratio. Frontiers of Environmental Science \& Engineering, 14(6): 115

Qi R, Qin D, Yu T, Chen M, Wei Y (2020). Start-up control for nitrogen removal via nitrite under low temperature conditions for swine wastewater treatment in sequencing batch reactors. New Biotechnology, 59: 80-87

Qian F, Gebreyesus A T, Wang J, Shen Y, Liu W, Xie L (2018). Singlestage autotrophic nitrogen removal process at high loading rate: Granular reactor performance, kinetics, and microbial characterization. Applied Microbiology and Biotechnology, 102(5): 2379-2389

Qian J, Zhang M, Wu Y, Niu J, Chang X, Yao H, Hu S, Pei X (2018). A feasibility study on biological nitrogen removal (BNR) via integrated thiosulfate-driven denitratation with anammox. Chemosphere, 208: 793-799

Qiao L, Ning X, Li Y, Zhang Y (2017). A kinetics study on anammox bacteria with a disproportionate substrate concentration. Journal of Chemical Technology and Biotechnology (Oxford, Oxfordshire), 92 (9): 2309-2316

Qiu S, Liu J, Zhang L, Zhang Q, Peng Y (2021). Sludge fermentation liquid addition attained advanced nitrogen removal in low $\mathrm{C} / \mathrm{N}$ ratio municipal wastewater through short-cut nitrification-denitrification and partial anammox. Frontiers of Environmental Science \& Engineering, 15(2): 26

Ren L F, Lv L, Zhang J, Gao B, Ni S Q, Yang N, Zhou Q, Liu X (2016). Novel zero-valent iron-assembled reactor for strengthening anammox performance under low temperature. Applied Microbiology and Biotechnology, 100(20): 8711-8720

Shen L, Liu S, He Z, Lian X, Huang Q, He Y, Lou L, Xu X, Zheng P, Hu B (2015). Depth-specific distribution and importance of nitritedependent anaerobic ammonium and methane-oxidising bacteria in an urban wetland. Soil Biology \& Biochemistry, 83: 43-51

Shi Y, Hu S, Lou J, Lu P, Keller J, Yuan Z (2013). Nitrogen removal from wastewater by coupling anammox and methane-dependent denitrification in a membrane biofilm reactor. Environmental Science \& Technology, 47(20): 11577-11583

Shore J L, M'Coy W S, Gunsch C K, Deshusses M A (2012). Application of a moving bed biofilm reactor for tertiary ammonia treatment in high temperature industrial wastewater. Bioresource Technology, 112: 51-60

Shu D, He Y, Yue H, Zhu L, Wang Q (2015). Metagenomic insights into the effects of volatile fatty acids on microbial community structures and functional genes in organotrophic anammox process. Bioresource Technology, 196: 621-633

Si Z, Peng Y, Yang A, Zhang S, Li B, Wang B, Wang S (2018). Rapid nitrite production via partial denitrification: Pilot-scale operation and microbial community analysis. Environmental Science. Water Research \& Technology, 4(1): 80-86

Soliman M, Eldyasti A (2018). Ammonia-Oxidizing Bacteria (AOB): opportunities and applications: A review. Reviews in Environmental Science and Biotechnology, 17(2): 285-321

Song Y, Ali M, Feng F, Chai X, Wang S, Wang Y, Tang C (2020). Performance of a high-rate anammox reactor under high hydraulic loadings: Physicochemical properties, microbial structure and process kinetics. Journal of Central South University, 27(4): 11971210

Stultiens K, Cruz S G, van Kessel M A H J, Jetten M S M, Kartal B, Op den Camp H J M (2019). Interactions between anaerobic ammoniumand methane-oxidizing microorganisms in a laboratory-scale sequencing batch reactor. Applied Microbiology and Biotechnology, 103 (16): 6783-6795

Tan H, Wang Y, Tang X, Li L, Feng F, Mahmood Q, Wu D, Tang C J (2020). Quantitative determination of cavitation formation and sludge flotation in Anammox granules by using a new diffusionreaction integrated mathematical model. Water Research, 174: 115632

Tang C J, Zheng P, Hu B L, Chen J W, Wang C H (2010). Influence of substrates on nitrogen removal performance and microbiology of anaerobic ammonium oxidation by operating two UASB reactors fed with different substrate levels. Journal of Hazardous Materials, 181 (1-3): 19-26

Tang C J, Zheng P, Wang C H, Mahmood Q, Zhang J Q, Chen X G, Zhang L, Chen J W (2011). Performance of high-loaded ANAMMOX UASB reactors containing granular sludge. Water Research, 45(1): 135-144

Thandar S M, Ushiki N, Fujitani H, Sekiguchi Y, Tsuneda S (2016). Ecophysiology and comparative genomics of nitrosomonas mobilis $\mathrm{ms} 1$ isolated from autotrophic nitrifying granules of wastewater treatment bioreactor. Frontiers in Microbiology, 7: 1869

Tomaszewski M, Cema G, Ziembińska-Buczyńska A (2017). Influence of temperature and $\mathrm{pH}$ on the anammox process: A review and metaanalysis. Chemosphere, 182: 203-214

van der Star W R L, Miclea A I, van Dongen U G J M, Muyzer G, Picioreanu C, van Loosdrecht M C M (2008). The membrane bioreactor: A novel tool to grow anammox bacteria as free cells. Biotechnology and Bioengineering, 101(2): 286-294

Wang G, Xu X, Zhou L, Wang C, Yang F (2017). A pilot-scale study on the start-up of partial nitrification-anammox process for anaerobic sludge digester liquor treatment. Bioresource Technology, 241: 181189 
Wang, H., Yu, G., He, W., Du, C., Deng, Z., Wang, D., Yang, M., Yang, E., Zhou, Y., Sanjaya, E.H., Chen, H., (2021). Enhancing autotrophic nitrogen removal with a novel dissolved oxygendifferentiated airlift internal circulation reactor: Long-term operational performance and microbial characteristics. Journal of Environmental Management, 296, 113271

Wang J, Hua M, Li Y, Ma F, Zheng P, Hu B (2019). Achieving high nitrogen removal efficiency by optimizing nitrite-dependent anaerobic methane oxidation process with growth factors. Water Research, 161: $35-42$

Wang S, Wang L, Deng L, Zheng D, Zhang Y, Jiang Y, Yang H, Lei Y (2017). Performance of autotrophic nitrogen removal from digested piggery wastewater. Bioresource Technology, 241: 465-472

Wen X, Gong B, Zhou J, He Q, Qing X (2017). Efficient simultaneous partial nitrification, anammox and denitrification (SNAD) system equipped with a real-time dissolved oxygen (DO) intelligent control system and microbial community shifts of different substrate concentrations. Water Research, 119: 201-211

Winkler M K H, Kleerebezem R, van Loosdrecht M C M (2012). Integration of anammox into the aerobic granular sludge process for main stream wastewater treatment at ambient temperatures. Water Research, 46(1): 136-144

Woebken D, Sayavedra-soto L A, Bottomley P J, Daims H, Wagner M (2020). Transcriptomic response of nitrosomonas Europaea transitioned from ammonia- to oxygen-limited steady-state growth. Applied Microbiology and Biotechnology, 5: 1-14

Wu Y J, Whang L M, Fukushima T, Chang S H (2013). Responses of ammonia-oxidizing archaeal and betaproteobacterial populations to wastewater salinity in a full-scale municipal wastewater treatment plant. Journal of Bioscience and Bioengineering, 115(4): 424-432

Wu Y J, Whang L M, Fukushima T, Huang Y J (2020). Abundance, community structures, and nitrification inhibition on ammoniaoxidizing archaea enriched under high and low salinity. International Biodeterioration \& Biodegradation, 153: 105040

Xie G J, Cai C, Hu S, Yuan Z (2017). Complete nitrogen removal from synthetic anaerobic sludge digestion liquor through integrating anammox and denitrifying anaerobic methane oxidation in a membrane biofilm reactor. Environmental Science \& Technology,
51(2): 819-827

Xie G J, Liu T, Cai C, Hu S, Yuan Z (2018). Achieving high-level nitrogen removal in mainstream by coupling anammox with denitrifying anaerobic methane oxidation in a membrane biofilm reactor. Water Research, 131: 196-204

Xu S, Wu X, Lu H (2021). Overlooked nitrogen-cycling microorganisms in biological wastewater treatment. Frontiers of Environmental Science \& Engineering, 15(6): 133

Yang J, Jiang H, Wu G, Hou W, Sun Y, Lai Z, Dong H (2012). Cooccurrence of nitrite-dependent anaerobic methane oxidizing and anaerobic ammonia oxidizing bacteria in two Qinghai-Tibetan saline lakes. Frontiers of Earth Science, 6(4): 383-391

Yang Y, Lu H, Shao Z, Liu S, Zhang Y, Jiang D, Gu L, He Q, Chai H (2020). Electron buffer formation through coupling thiosulfatedependent denitratation with anammox in a single-stage sequencing batch reactor. Bioresource Technology, 312: 123560

Yokota N, Watanabe Y, Tokutomi T, Kiyokawa T, Hori T, Ikeda D, Song K, Hosomi M, Terada A (2018). High-rate nitrogen removal from waste brine by marine anammox bacteria in a pilot-scale UASB reactor. Applied Microbiology and Biotechnology, 102(3): 15011512

Zhang G, Zhang L, Han X, Zhang S, Peng Y (2021). Start-up of PNanammox system under low inoculation quantity and its restoration after low-loading rate shock. Frontiers of Environmental Science \& Engineering, 15(2): 32

Zhang L, Narita Y, Gao L, Ali M, Oshiki M, Ishii S, Okabe S (2017). Microbial competition among anammox bacteria in nitrite-limited bioreactors. Water Research, 125: 249-258

Zhang X, Zheng S, Zhang H, Duan S (2018). Autotrophic and heterotrophic nitrification-anoxic denitrification dominated the anoxic/oxic sewage treatment process during optimization for higher loading rate and energy savings. Bioresource Technology, 263: 8493

Zhou X, Song J, Wang G, Yin Z, Cao X, Gao J (2020). Unravelling nitrogen removal and nitrous oxide emission from mainstream integrated nitrification-partial denitrification-anammox for low carbon/nitrogen domestic wastewater. Journal of Environmental Management, 270: 110872 